No 2006 - 05

March

THTOER PROSPCTIVER

ET D'InFOnMATIONS

INTHENA TIONALE:

\title{
China's Emergence and the Reorganisation of Trade Flows in Asia
}

\author{
of Trade Flows in Asia
}

Guillaume Gaulier, Françoise Lemoine \& Deniz Ünal-Kesenci 
China's Emergence and the Reorganisation of Trade Flows in Asia

Guillaume Gaulier, Françoise Lemoine \& Deniz Ünal-Kesenci

No 2006 - 05

March 
China's Emergence and the Reorganisation of Trade Flows in Asia

\section{TABLE OF CONTENTS}

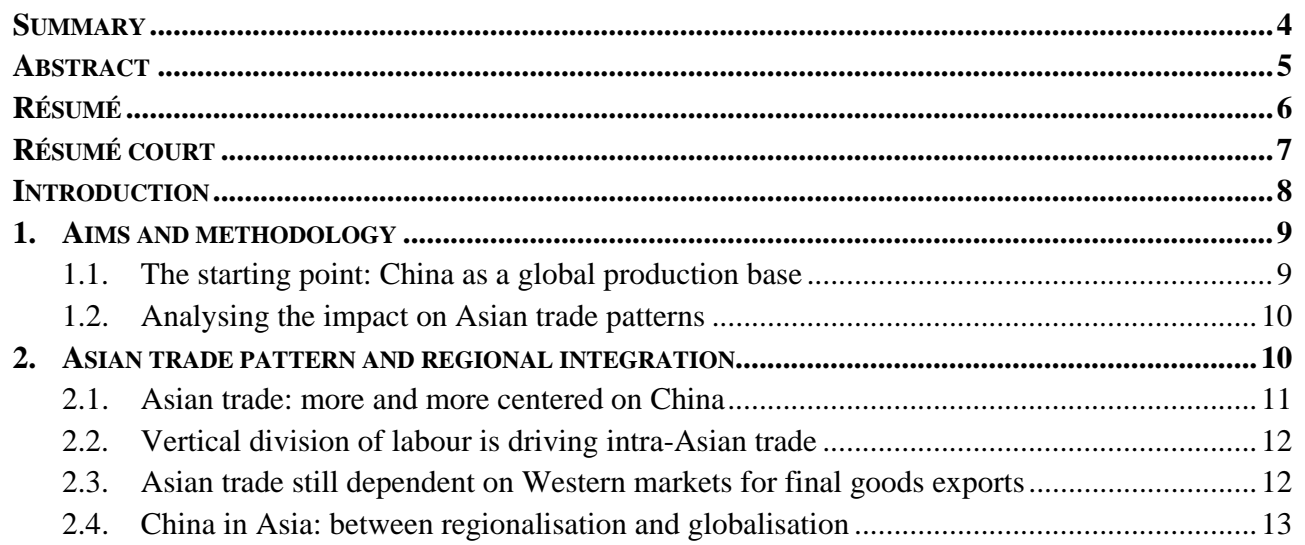

3. ADVANCED ASIAN ECONOMIES: THE SHOCK OF THE INTERNATIONAL REORGANISATION

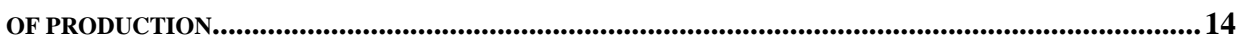

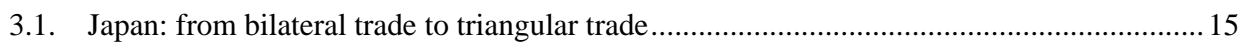

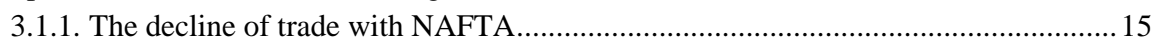

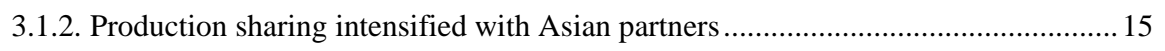

3.1.3. The international reorganisation of production in electronics ..................................17

3.2. The Dragons: trade switched away from advanced economies to China ............................. 18

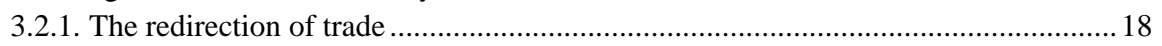

3.2.2. Dragons export P\&C to China and final goods to NAFTA and Europe ..................... 18

3.2.3. Imports switched from Japan to China .................................................................... 19

4. EMERGING ECONOMIES: THE THREAT OF CHINA's PRICE COMPETITION.........................................19

4.1. The Tigers have resisted to China's competition in up-market products .............................19

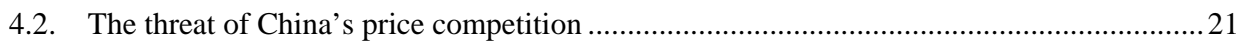

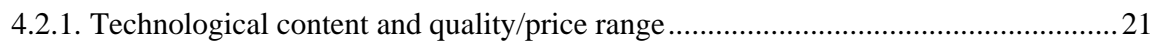

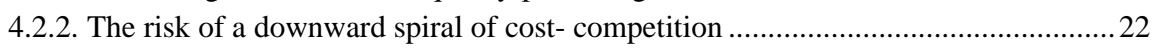

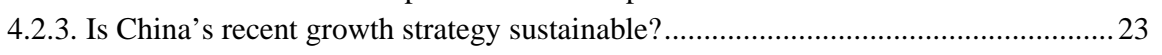

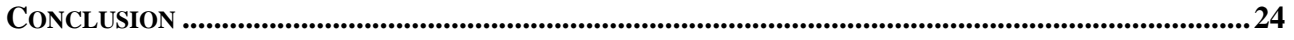

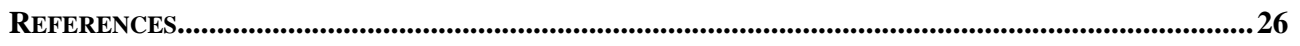

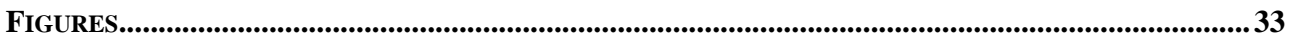

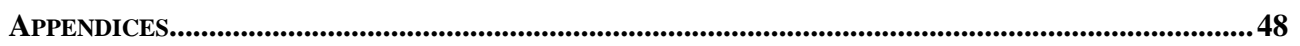

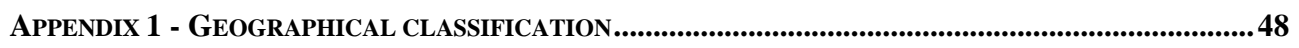

APPENDIX 2 - BACI: AN ANALYTICAL DATABASE ON INTERNATIONAL TRADE .................................49

APPENDIX 3 - CLASSIFICATION BY “QUALITY-PRICE” RANGE ..............................................................5 50

APPENDIX 4 - CLASSIFICATION BY PRODUCTION STAGE ACCORDING TO THE BEC ..............................52

APPENDIX 5 - THE DEFINITION OF HIGH-TECH PRODUCTS ..................................................................53

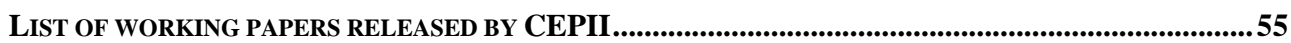




\section{CHINA'S EMERGENCE AND THE REORGANISATION OF TRADE FLOWS IN ASIA}

\section{SUMMARY}

China became the third largest exporter in the world in 2004 and is expected to become the largest by the beginning of the next decade. The present study aims at investigating how this surge China has altered the other Asian countries' specialisations and has influenced regional integration. This paper tries to provide answers to the following questions: What have been the effects of China's rise on regional integration in Asia? Has China become an engine of trade in the region? How has the position of advanced Asian economies evolved : i.e. Japan and the Dragons (Hongkong, Singapore, South Korea and Taiwan) in the division of labour, since China has become a global manufacturing base? Has China's trade expansion been achieved at the expense of other emerging economies in South-East Asia (the Tigers, i.e. Malaysia, Philippines, Thailand)?

The detailed analysis of trade flows during the period 1993-2003 shows that the rise of China has intensified the international segmentation of production processes among Asian partners but has not (yet?) created an autonomous engine for regional trade, which still depends on outside markets for final goods exports. The positions of advanced economies, the US and Japan, in Asian trade have been considerably weakened, as the regionalisation process has moved large volumes of production to low cost sites. As China has become an export platform for multinational firms, the driving force of Japan's trade has shifted from exporting final goods to North America and Europe towards exporting parts and components to China, and from importing final goods from America, Europe and the Dragons towards importing these goods from China. The Dragons' trade has also switched away from Japan and NAFTA and towards China. The reorganisation of production has weakened trade between the advanced economies but up to now has not severely affected the position of the emerging Asian economies (Malaysia, Philippines, Thailand) in international trade.

However, the surge of China's exports associated with the continuous decline of its export prices since 1997 suggests the risk of a downward spiral of cost-competition, as China's prices exert downward pressure on international prices of manufactured products. The question is raised concerning the sustainability of China's recent growth strategy, which has led to a sharp deterioration of its terms of trade and may result in the multiplication of trade disputes. 
China's Emergence and the Reorganisation of Trade Flows in Asia

\begin{abstract}
The emergence of China has intensified the international segmentation of production processes within Asia, but has not created an autonomous engine for the region's trade, as Asia still depends on outside markets for its final goods exports. The reorganisation of production has weakened the position of the advanced economies (Japan and the US) in Asia's trade, but up to now has not severely affected the position of the emerging Asian economies (Malaysia, Philippines, Thailand). However, the surge of China's exports and the decline of its export prices, suggest the risk of a downward spiral of cost-competition, while the deterioration of China's terms of trade raises the question of the sustainability of its recent growth strategy.
\end{abstract}

Classification JEL: F14 ; F15 ; F2 ; 053.

Keywords: $\quad$ China; Asia; trade; regional integration; specialisation. 


\section{RESUME}

La Chine est devenue en 2004 la deuxième puissance exportatrice mondiale et devrait devenir la première au début de la prochaine décennie. Cette étude a pour but d'analyser comment la montée en puissance de la Chine a modifié les spécialisations des autres pays asiatiques et influencé le processus d’intégration régionale. Il tente de répondre aux questions suivantes; Quels ont été les effets de la montée de la Chine sur l'intégration régionale en Asie ? La Chine est -elle devenue le moteur des échanges dans la région ? Comment a évolué la position des économies développées de la région, c'est-à-dire le Japon et les Dragons (Corée du Sud, Hongkong, Singapour, Taiwan) dans la division internationale du travail depuis que la Chine est devenue un base de production globale pour les industries manufacturières ? L'expansion commerciale chinoise s'est elle faite au détriment des autres pays émergents d'Asie du sud-est (les Tigres, c’est-à-dire la Malaisie, les Philippines et la Thaïlande) ?

L'analyse approfondie des flux d'échanges sur la période 1993-2003 montre que l'émergence de la Chine a entraîné une intensification de la segmentation internationale des processus de production entre les partenaires asiatiques mais qu'elle n’a pas (encore?) créé un moteur autonome pour le commerce de la région dont les exportations de produits finals dépendent toujours de marchés extérieurs à la zone. Les positions des économies avancées, les Etats-Unis et le Japon, dans le commerce régional se sont considérablement affaiblies, à mesure que le processus de régionalisation a déplacé d'importants volumes de production vers les pays à bas coûts. La Chine étant devenue une plate-forme d'exportation pour les firmes multinationales, le moteur des exportations du Japon ne réside plus dans ses exportations de produits finals vers l'Amérique du nord et l'Europe mais dans celles de pièces et composants vers la Chine, et le moteur de ses importations ne réside plus dans celles de produits finals en provenance des pays développés mais en provenance de Chine. La réorganisation des productions industrielles a affaibli les échanges entre pays développés mais jusqu’à, présent elle n’a pas sérieusement affecté la position des pays émergents d’Asie (Malaisie, Philippines, Thaïlande) dans le commerce international.

Cependant, l'expansion des exportations chinoises associée à la baisse continue de leurs prix depuis 1997 peut faire craindre que la concurrence par les coûts ne conduise à une spirale de baisse de prix , car les prix chinois exercent une pression à la baisse sur les prix mondiaux des produits manufacturés. Cela pose la question de la soutenabilité de la stratégie de croissance suivie par la Chine ces dernières années, dans la mesure où celle-ci a entraîné une détérioration sensible des ses terme de l'échange et risque de provoquer la multiplication de conflits commerciaux. 
China's Emergence and the Reorganisation of Trade Flows in Asia

\section{RESUME COURT}

L’émergence de la Chine a intensifié la segmentation internationale des processus de production en Asie mais n'a pas jusqu'ici créé de moteur autonome pour les échanges de la région dont les exportations de produits final dépendent toujours de marchés extérieurs à la zone. La réorganisation des productions a considérablement affaibli les positions des économies développées (Japon, Etats-Unis) dans les échanges de la zone, mais n’a pas sérieusement affecté celles des pays émergents (Malaisie, Philippines, Thaïlande). Cependant l'essor des exportations chinoises et la baisse de leurs prix peut faire craindre que la concurrence par les coûts ne mène à une spirale de baisse de prix, et la détérioration des termes de l'échange du pays soulève la question de la soutenabilité de sa récente stratégie de croissance.

Classement JEL : $\quad$ F14 ; F15 ; F2 ; O53.

Mots Clés : $\quad$ Chine ; Asie ; commerce ; intégration régionale ; spécialisation. 


\title{
CHINA'S EMERGENCE AND THE REORGANISATION OF TRADE FLOWS IN ASIA
}

\author{
Guillaume Gaulier, Françoise Lemoine \& Deniz Ünal-Kesenci ${ }^{1}$
}

\section{INTRODUCTION}

For the last two decades, China's rise in international trade has been outstanding. China's share in international trade more than trebled, jumping from less than $2 \%$ in 1985 to about $7 \%$ in 2005. China has become the third largest exporter in the world in 2004 and is expected to become the first largest by the beginning of the next decade (OECD, 2005). China has achieved such performance thanks to a strong involvement in the international division of labour. Production sharing between China and its neighbours has led to a reorganisation of industrial production in Asia and has propelled China at the top of world exporters. The present study aims at investigating how the surge of China's has led to changes in other Asian country specialisation and in regional integration during the period 1993-2003.

This paper tries to provide answers to the following questions:

What has been the effect of China's rise on regional integration in Asia? Has China become an engine of international trade in the region?

How has evolved the position of advanced Asian economies i.e. Japan and the Dragons (Hongkong, Singapore, South Korea and Taiwan) in the division of labour in Asia since China has become a global manufacturing base?

Has China's trade expansion been achieved at the expense of other emerging economies in South-East Asia (the Tigers, i.e. Malaysia, Philippines, Thailand)?

The paper is organised in four sections. The first section sets the aims and the method. The second section presents an overview of Asian trade ${ }^{2}$. The third section focuses on changes that took place in the trade pattern of Asian advanced economies (Japan and the Dragons) as a result of the international reorganisation of production. The fourth section focuses on the trade position of Asian emerging economies (the Tigers) and addresses the question of China's price competition.

\footnotetext{
1 This is a revised version of a paper presented at the Conference on "Law, Finance and Economic Development in China”, University of Fudan, Shanghai, 10-11 September 2005 and at the 5th International Conference on the Chinese Economy "China in the World Economy: Internal Challenges and international Challenges”, CERDI-IDREC, Faculté de Sciences Economiques et de Gestion, Université d'Auvergne, 2021 October 2005.

Contact: francoise.lemoine@cepii.fr

In the text, the term Asia encompasses Oceania (see tables and Appendix 1 for the definition of geographic areas).
} 


\section{AIMS AND METHODOLOGY}

\subsection{The starting point: China as a global production base}

China's emergence in world trade is inseparable of changes in the way industrial production is organised internationally. In the 1990s, firms have expanded their cross border production and trade networks, especially in East Asia, and have integrated China in their global networking (Yusuf et alii, 2004, Steinfeld, 2004, Ernst 2004). International production has become a major determinant of trade pattern and China has become a global manufacturing base for multinational firms, as evidenced by the analysis of China's trade statistics.

The detailed data coming from China's Customs Statistics made it possible to analyse China's foreign trade flows depending on the ownership of exporting and importing firms (Chinese firms, firms with foreign capital, wholly-foreign firms), and depending on the customs regime (assembly trade or "ordinary trade"). Using these data, the CEPII research work has shown that the largest and most dynamic part of China's foreign trade results from the outsourcing strategies of foreign firms which have heavily invested in the mainland. This work has provided a quite precise image of China as a global production base (Lemoine and Ünal-Kesenci, 2004; Gaulier, Lemoine and Ünal-Kesenci, 2005). The following findings stand out:

Assembly and processing of imported inputs for re-export account for about half of China's foreign trade. These activities have been the most dynamic part of China's exports since the early 1990s and have allowed for their rapid diversification from textile to electronics. Assembly and processing is responsible for China's entire trade surplus with the US and Europe.

Foreign firm affiliates account for more than half of China's total trade and they carry out the overwhelming share of processing trade (80\%). This reflects the outsourcing strategy of firms which have transferred to the mainland the labour intensive stages of production processes (Table 1).

The bulk of inputs that China imports for re-export comes from East Asia, as production moved mainly from East Asian advanced economies to the mainland. The supply of intermediate goods to processing facilities in China has driven the expansion of East Asian trade with China. This trade involves East Asian firms but also US and European firms operating in East Asia.

China's trade in high-tech goods has increased rapidly, but the overwhelming share (80\%) is handled by foreign affiliates and takes place mainly with Asian partners. China's hightech trade thus reflects the country's position in the international segmentation of production process more than the actual upgrading of its domestic capabilities. 


\subsection{Analysing the impact on Asian trade patterns}

The aim of the present paper is to examine how this emergence of China as a global manufacturing base in Asia has affected the position of other Asian countries in the international division of labour.

The paper focuses on Japan and two groups of countries aggregated according to their level of economic development: the Dragons, i.e. the first tier of New industrialised economies (Hongkong, Singapore, South-Korea, Taiwan), and the Tigers, i.e. the second tier of New industrialised economies (Malaysia, Philippines and Thailand). The evolution of their geographic trade pattern is analysed, focusing on their trade with the selected groups of countries in Asia and in the rest of the world (NAFTA and Western Europe).

The CEPII data base on international trade $\mathrm{BACI}^{3}$, has made it possible an original analysis of trade flows over the period $1993-2003^{4}$, using different criteria). A first classification gives the composition of trade by stage of production, using the United Nations 'Broad Economic Categories (BEC, see Appendix 4) which distinguishes five categories of products: 1) Primary products, 2) Semi-finished goods, 3) Parts and Components (P\&C), 4) Capital goods, 5) Consumption goods. The structure of trade by stage of production is helpful to show how the international division of labour between the different Asian partners has evolved. A second criteria is the unit value of traded goods, which is used to assess the specialisation of Asian exporters according to price/quality range as well as the evolution of their terms of trade (Appendix 3). A third criteria of classification relies on the technological content of trade goods and measures the technological upgrading of the different countries' exports (Appendix 5). Combining these different criteria, the analysis provides useful insights into the conditions of competition and the existing complementarity between the countries in the region.

\section{ASIAN TRADE PATTERN AND REGIONAL INTEGRATION}

The pattern of Asia's trade on the period observed (1993-2003) shows that the emergence of China has fostered the regionalisation as well as the globalisation processes. The following trends characterise the region's trade:

- China's is overtaking Japan as the major trading power in the region,

- the segmentation of production processes is the main force driving regional trade

- Asian exports of final goods are still heavily dependant of markets outside the region

- China has boosted intra-regional trade but is itself more and more integrated in a world-wide division of labour.

"Analytical Database on International Trade. For a description of the data base BACI, see Appendix 2 and the CEPII website: http://www.cepii.fr/anglaisgraph/bdd/baci.htm.

Despite the treatment made in the construction of the data base, the quality of the data for the period prior to 1993 may be affected by the lack of export and import declaration for a number of countries. Therefore, the present analysis will focus on 1993-2003. 


\subsection{Asian trade: more and more centered on China}

The share of Asia ${ }^{5}$ in world trade of manufactured products has not changed much between 1993 and 2003. Asia's share declined slightly in world exports (from 31.7\% to 31.3\%), but more markedly in world imports (from $25.2 \%$ to $24 \%$ ). The gap between export and import shares thus enlarged indicating that Asian trade surplus with the rest of the world tended to increase over this period (Table 2).

Intra-Asian trade as a share of world trade of manufactured products increased only slightly, from less than $14.8 \%$ in 1993 to $15.4 \%$ in 2003 . In fact, the relative importance of intra-regional trade increased much more in Asian imports (from 58\% to 64\%) than in Asian exports (from $47.5 \%$ to $50 \%$ ). The dependence on outside markets has thus remained more pronounced than the dependence on outside suppliers, a point that will be analysed below.

Large shifts occurred in the respective contributions of the different Asian countries or groups of countries to world trade. Japan's share in world exports declined sharply, dropping from $12.5 \%$ to $7.5 \%$, and more moderately in world imports, from $5.1 \%$ to $4 \%$. China's share rose from $3.8 \%$ to $7.7 \%$ of world exports, thus making up for most of Japan's decline; it rose from $3.2 \%$ to $5 \%$ of world imports, thus more than offsetting Japan's decline. The diverging trends of Japanese and Chinese foreign trade correspond to their contrasted macroeconomic performance. While Japan's economy stagnated, China posted a record economic growth accompanied by a rapid opening up. China's economy is more open to trade and FDI than the Japanese economy has ever been. It is worth noting that during this period, the Tigers succeeded in improving their positions in world exports (it rose from 3\% to 3.8\%), but stepped back in world imports, and so did the Dragons. In fact, China and India were the only Asian countries which strengthened their positions in world imports during this period.

Similar shifts in the respective weights of the different countries occurred in intra-Asian trade of manufactured products, which has become more and more centred on China (Table 3). China's share increased from around 12-14\% of intra-regional trade in 1993 to more than $20 \%$ in 2003. China had almost caught up with Japan as the major exporter of manufactured products to the region and has overtaken Japan as the major importer of Asian manufactured goods. China's trade increased at an accelerated pace with all Asian countries/groups of countries and the most important increase took place between China and the Dragons. In 2003 China received one third of the Dragons' exports to the region, one fourth of Japan's exports, and one sixth of Tigers' exports. China supplied 40\% of Japanese imports from Asia; 30\% of Dragons’ imports from Asia.

\footnotetext{
5 Cf. note 2 .
} 


\subsection{Vertical division of labour is driving intra-Asian trade}

There are several ways to assess the extent of vertical division of labour, i.e. the splitting up of the value added chain between different countries (Lall et alii, 2004). The method used in present study is to measure the share of parts and components (P\&C) in total trade. It provides clear evidence that the segmentation of production processes has been the engine of Asian trade.

Since the early 1990s, P\&C have been the fastest growing product category in Asian trade. P\&C accounted for 24\% of Asian exports and 25\% of Asian imports in 2003, while the corresponding figures were $18 \%$ and $16 \%$ ten years earlier. P\&C have almost caught up consumption goods as the most important export category and have by far overtaken capital goods and consumption goods in the region's imports (Figure 1).

Compared with other parts of the world, Asia appears to be relatively specialised in P\&C and this specialisation has increased since early 1990s. Asia's share in world exports of P\&C (38\% in 2003) is significantly higher than its share in overall world exports (29\%, Figure 2). This reflects the fact that East Asia has become a manufacturing hub, especially in electronic industry, a sector in which production sharing has been an especially widespread phenomena (Sturgeon and Lester, 2004; Ernst, 2004).

In fact Asian trade in P\&C has been more and more concentrated within the region, as the international fragmentation of production processes has intensified within Asia. Between 1993 and 2003, the share of intra-regional trade in Asian exports of P\&C increased from less $50 \%$ to more than $60 \%$. On the import side this share rose from $61 \%$ to $69 \%$ (Table 4). In 1993, the overwhelming share of intra-Asian trade in P\&C took place between Japan and the New industrialised economies (Dragons and Tigers) as industrial firms in Japan had established production platforms in East Asia. But from 1993 to 2003, China was responsible for most of the acceleration of trade in $\mathrm{P} \& \mathrm{C}$ in the region, as firms from advanced economies (Japan, the Dragons) have focused to China as a new location for their labour-intensive stages of production. To a large extent, China's involvement in the division of labour thus explained the rise of intra-regional trade in $\mathrm{P} \& \mathrm{C}$ over this period.

\subsection{Asian trade still dependent on Western markets for final goods exports}

The intensified segmentation of production processes within the region has tended to accentuate the structural asymmetry of Asia's trade with the rest of the world.

Since 1993, Asian trade surplus with the rest of the world has skyrocketed and has stemmed mainly from trade in final goods. Trade balance by stage of production shows that Asian countries taken together hold by far their largest comparative advantage (structural trade surplus) with the rest of the world in consumption goods, and to a lesser extent in capital goods. While the segmentation of production processes has boosted intra-Asian trade in P\&C, Asia taken as a whole increasingly depends on the rest of the world for its exports of final goods: its ballooning trade surplus in final goods indicates that the final demand, 
which eventually drives the international segmentation of production processes within the region, is still located outside the region (Figure 1C).

From 1993 to 2003, Europe's and America's trade displayed opposite trends: the former strengthened its position in international trade while the latter lagged behind; but both expanded their trade with China at an accelerated pace (Table 5). The share of European imports in world trade enlarged (by 2.6 percentage points) and two major flows accounted for this acceleration : intra-European trade (+2.3 percentage points) and imports from China $(+1.1)$. The rise of China in European imports more than compensated the relative decline of other Asian economies resulting from the move of production from East Asian advanced economies to China. America's share in global imports contracted (-1.8 percentage point) and this affected imports from all regions, excepted those from China (which recorded a gain of 1.2 percentage point in world trade) and from Europe $(+0.3)$. The share of advanced Asian economies in American imports fell back abruptly, and their loss was bigger than China's gain. While the share of Asia remained unchanged in European imports (6\%), it contracted slightly in American imports (from 9\% to 8\%), remaining however relatively large.

As on the import side, the rise of European exports in world trade (+2.0 percentage point) was mainly due to intra-regional trade $(+2.3)$ and to a much lesser extent to China $(+0.2)$ and America (+0.3). The rise of China in Europe's exports did not compensate for the slowdown of exports to advanced Asian economies, and the overall share of Asia contracted. American exports lost ground in global trade (-3.7 percentage point), and only exports to China grew faster than average. In America's exports, the share of Asia fell abruptly. The trade deficit of Europe and America with Asia enlarged. Asian trade imbalances reflect the pattern of economic growth in most Asian economies, in which domestic consumption still remained a relatively weak component of demand (ADB, 2005).

\subsection{China in Asia: between regionalisation and globalisation}

Regionalisation, i.e. the geographic concentration of trade between neighbour countries, is a widespread characteristic of international trade. Geographic proximity is naturally an important determinant of trade patterns. Recent studies have observed that regional polarisation increased in the nineties in America and in Asia-Oceania (Gaulier, Jean and Ünal-Kesenci, 2004). This trend towards regionalisation results both from institutional factors, as evidenced by the multiplication of regional trade agreements in the 1990s, and from the strategies of firms. Multinational firms have moved high volume production in low-cost sites within blocs and this regional organisation has corresponded to a growing need for rapid response, build-to-order, etc. Trade agreements have strengthened these regional production networks (Sturgeon and Lester, 2004).

Splitting up the world into three large areas, Europe-Africa, Asia-Oceania and America clearly shows that intra-regional trade accounts for the most important part of international trade of manufactured products (Table 6). The concentration has reached its highest level in Europe-Africa, where $78 \%$ of exports and $76 \%$ of imports are carried out within the 
region, a ratio which has tended to increase since 1993. In America, trade concentration within the region remained relatively low and stable on the import side (43\% in 2003), but increased fast on the export side since the mid nineties, rising from 52\% in 1993 to 58\% in 2003. The US market plays a central role in the evolution of intra-regional trade.

In Asia, imports became more concentrated within the region (intra-regional imports rose from $59 \%$ in 1993 to $65 \%$ of total imports in 2003) while the share of intra-regional trade in exports increased more moderately (from $47 \%$ to $49 \%$ ) and remained at a much lower level. Again, the Asian trade pattern reflects the absence of a large market with a dynamic domestic demand which would drive trade and economic growth in the region. Indeed China's emergence has boosted intra-regional trade as China's imports from Asia have increased at an accelerated pace. However, less than half of these imports are aimed at China's domestic market while more than half is for processing and export. Although imports for the domestic market have increased faster than for processing since 1997, China's imports from its Asian partners still heavily depends on the evolution of world markets and especially on the US market (Gaulier, Lemoine, Ünal-Kesenci, 2005).

While China's emergence has favoured intra-regional trade, its trade is relatively less concentrated on Asia than that of other Asian countries on average. Large-sized economies usually display less regional polarisation, as their market is large enough to attract distant suppliers. From 1993 to 2003, the share of Asia fell from 56\% to 45\% in China's exports while it increased in the case of Japan's, the Dragons and Tigers, reaching respectively $48 \%, 58 \%$ and $57 \%$ of their exports. On the import side, the concentration on Asia of China's trade rose slightly from $59 \%$ to $63 \%$, but less rapidly than in the cases of Japan, Dragons and Tigers.

The low cost of labour, as well as other advantages such as economies of scales, spatial concentration and the size of the potential and actual market, clearly make China a target for the investment and outsourcing strategies of firms all over the world. China is in fact engaged in a world-wide division of labour, as shown by the geographic pattern of trade in P\&C, which is relatively less dependent on Asia than other East Asian country trade. In 2003 China directed to Asia 55\% of its P\&C exports and sourced from Asia 66\% of its P\&C imports, while for East Asia the respective share was $62 \%$ and $72 \%$. This may suggest that the emergence of China as a global production base may reverse the trend towards regionalisation of world trade as it threatens the advantages that have been associated with geographic proximity.

\section{ADVANCED ASIAN ECONOMIES: THE SHOCK OF THE INTERNATIONAL REORGANISATION OF PRODUCTION}

This second part of the paper turns to the changes that have taken place in the trade pattern of advanced Asian economies, Japan and the Dragons, following China's emergence as a global manufacturing base. The reorganisation of industrial production has strongly affected their trade with their most important partners in Asia and in the rest of the world and has led to far-reaching changes in the composition of their trade by stage of production. 


\subsection{Japan: from bilateral trade to triangular trade}

\subsubsection{The decline of trade with NAFTA}

As noted above, Japan's weight in world trade as well as in Asian trade, has dropped abruptly since the end of the early 1990s, as the Japanese economy has entered a period of protracted stagnation. In this context, the changes that have marked Japan's trade appear to be driven by two intricate factors: the regionalisation process on both sides of the Pacific rim and the move of production to low-cost countries. The major shifts in the geographic pattern of Japan's trade were the decline of NAFTA and the emergence of China as a major partner. Underlying these changes, the segmentation of production processes with Asian partners intensified as evidenced by the rapid expansion of Japan's trade in P\&C.

The decline of NAFTA in Japan's imports was sharp (Figure 3B). Up to the end of the 1990s, NAFTA was by far Japan's major supplier but by 2003 it had lost this position to China: NAFTA share in Japan's imports fell from 26\% to 18\% from 1993 to 2003, while that China rose from $9 \%$ to almost $20 \%$. It is worth noting that during this period, there was a symmetric decline of Japan's weight in NAFTA exports (from 9\% to 5\%). The agreement on the North American Free Trade Area came into force in 1995 and strengthened regional integration: exports became more concentrated within the region as the US and Mexican markets have absorbed an increased share of NAFTA exports. The importance of East Asian markets (Japan, Dragons and Tigers) diminished abruptly. This shift in favour of intra-regional trade was mainly driven by US imports: whereas in 1993, US imports from East Asia were bigger than its imports from the NAFTA (respectively 34\% and 27\%), since 1996 the reverse has been true as imports from NAFTA have overtaken imports from East Asia (they accounted respectively for 30\% and 28\% in 2003).

The geographic pattern of Japan's exports underwent more limited changes than its imports, although the rise of the Chinese market was remarkable (rising from 5\% to $12 \%$ of Japan's exports, Figure 3A).

\subsubsection{Production sharing intensified with Asian partners}

Production sharing between Japan and other Asian economies intensified, as evidenced by the accelerated growth of trade in P\&C (Figure 4). P\&C have become the most important export category, overtaking capital goods and accounting for 31\% of Japan's total exports in 2003. Imports of P\&C also increased at an accelerated pace (doubling its share to 15\% of total imports) but Japan has remained a net supplier of P\&C, thus keeping its leading position in the international division of labour, while late-comers, like China, are specialised in assembly. Japan's trade in P\&C has been increasingly concentrated within Asia which accounts for 51\% of its exports and 58\% of its imports in 2003 (against respectively $38 \%$ and $34 \%$ in 1993). This trend is mainly due to trade with China which has considerably enhanced its importance and has jut overtaken the Tigers in Japan's exports and imports. Nevertheless, the Dragons have remained the most important partners (which may be partially due to the trade flows transiting through Hongkong). All Asian 
partners have considerably strengthened their positions as suppliers of P\&C for Japan's industry (Figures 5 \& 6). The role of “western" partners (NAFTA and Europe) plummeted. In fact, NAFTA lost the dominant position it had in early 1990s as a market and supplier of Japanese industry . Europe also lost ground as a supplier of P\&C, but kept a stable share as a market. A similar story underlies Japan's exports of semi-finished goods, which go mainly to the Dragons and more and more to China. Production sharing with Asian partners has thus been the engine of changes in Japan's trade.

The supplies of Japanese P\&C to China are mainly directed to foreign export platforms setup in the mainland. Processing activities play a dominant part in bilateral trade: in 2002, according to China's customs statistics, 60\% of China's imports from Japan's was for processing (Gaulier, Lemoine, Ünal-Kesenci, 2005). This move of the final stage of production to China has had major consequences.

The first consequence is that Japan's imports of final goods shifted from advanced economies to China (Figure 6). China has become by far Japan's first largest supplier of consumption goods, accounting for 1/3 of its global imports in 2003 (against 17\% ten years earlier). This switch occurred mainly at the expense of the Dragons which lost most of their market share. Japan's imports of capital goods have also shifted to China, which increased its share from $4 \%$ to $26 \%$, at the expense of NAFTA and Europe (the cumulated share of these two regions fell from $75 \%$ in early nineties to $45 \%$ in 2003). Most of capital goods exported from China consist of electronic products (telecommunication equipment and computer). Japan has thus shifted from a situation in which it imported final goods mainly from the US, Europe and the Dragons, to a situation in which its imports mainly come from China.

The second consequence of China's emergence as export plate-form is that Japan's exports of capital goods slowed down (falling from 31\% of total exports to 25\% between 1993 and 2003). One of the reason for that is that China has become a major exporter of final goods to the US, having recently overtaken Japan as its supplier of capital goods and consumption goods.

The changes that have taken place in Japan's trade pattern as a result of China's emergence can be viewed as a switch from bilateral to triangular trade. Japan's trade which used to be dominated by the exports of final goods to North America and Europe has been driven by exports of P\&C and semi-finished goods to China where they are processed and assembled and then re-exported to Western markets and also to Japan.

The changes observed in Japan's trade stem from the strategies of firms which have moved high volume of production to low-cost sites within blocs (Sturgeon and Lester 2004). As a consequence, Japan's trade with China has rapidly increased, while its imports from advanced economies, and mainly from the US (which accounts for the bulk of NAFTA trade with Japan), have slowed-down. A symmetric trend happened in North America: US imports shifted in favour of low-cost suppliers in the region (Mexico) and in China, and away from Japan and the Dragons. Thus, contrary to expectations, China's rise has not 
taken place at the expense of Asian emerging economies (the Tigers) but has induced a slow-down of trade between advanced economies.

\subsubsection{The international reorganisation of production in electronics}

Electronic industry plays a crucial part in Asian industry and trade as it is the sector in which the international segmentation of production processes is the most advanced (Ernst, 2004). In 2003, electronics was the first most important branch in Japan's foreign trade, accounting for around $30 \%$ of its exports and $20 \%$ of imports.

The direction of Japan's electronic exports underwent dramatic changes as it switched from traditional markets in the US and the EU (each representing still 20\% of Japan's electronic exports in 2003) to new dynamic markets in Asia: the Dragons (28\%) and China (almost 15\%, (Figure 6bisA). During the decade, the value of Japan's electronic exports to the US fell and it lost most of its market share. This rapid changes reflected both the reorganisation of production in Asia which boosted emerging countries' exports (Tigers and China) and the integration process within NAFTA which favoured US imports from Mexico.

The reorganisation of production implied far-reaching changes in the commodity composition of Japanese exports, which switched from capital goods to P\&C. From early 1990s to 2003, P\&C share rose from 35\% to 50\% of total electronic exports, while capital good exports dropped correspondingly (from 50\% to 32\%). Production sharing has led to a rapid rise of Japan's P\&C exports to the Dragons and China which have become the two major export destinations, the former receiving 35\% of Japanese electronic P\&C in 2003, and the latter 17\% (Figure 6bisB).

For Japan's capital good exports, Europe and NAFTA have remained by far the major markets but not the most dynamic. In fact Japanese capital goods have lost ground at an accelerated pace in the US market and have been overtaken since early 2000 by Mexico and China which has become the first largest supplier of the US in this category of products in 2003.

In Japans' imports of electronic goods, Asian countries strengthened their positions as the US abruptly fell back (from 50\% in 1989 to less than 20\% in 2003). Dragons have become the major supplier (more than $20 \%$ of imports), almost caught up by China (Figure 6bisC). The switch in favour of China was especially outstanding in capital goods and China has become its first largest supplier accounting for more than $25 \%$ of Japan's electronic capital goods imports in 2003 (Figure 6bisD).

The emergence of China as a global manufacturing base has thus led to tremendous changes in the trade specialisation of electronic industry in Japan. 


\subsection{The Dragons: trade switched away from advanced economies to China}

The factors which have determined the evolution of Japan's trade pattern have led to similar changes in the Dragons' trade. Trade in P\&C has increased at an accelerated pace and China has enlarged its position at the expense of developed economies. It must be mentioned that trade flows of the Dragons are blurred with transit trade taking place through Hongkong.

\subsubsection{The redirection of trade}

The major changes in the geographic trade pattern of the Dragons were the following (Figure 7):

The role of Japan as a trade partner of the Dragons, and especially as a supplier declined abruptly. The decline was the result of two factors: first, the relative slow growth of Japanese overall trade, since the share of the Dragons in Japan's trade was almost stable, as noted above; second, the development of export capacities in China which reduced the role of Japan as an exporter of final goods to the Dragons' (and reciprocally).

The importance of NAFTA also fell and in 2003, it has ceased to be the Dragons's major market. This trend is mirrored by the decline of the Dragon's in NAFTA trade. Like Japan's, the Dragons' trade has been affected by the move of production to low cost suppliers both in Asia and in America.

The symmetric change was the intensification of trade with China. Since the mid 1990s, Dragons' trade with China has skyrocketed, and in early 2000s, China has become their first largest market and first largest supplier.

As in the case of Japan, the sourcing strategy of multinational firms is at the core of trade expansion between the Dragons and China: according to China's Customs statistics, twothirds of China's exports to the Dragons and $60 \%$ of its imports correspond to processing activities; foreign affiliates play a dominant part as they handle more than $60 \%$ of trade between the Dragons and China (Gaulier, Lemoine and Ünal-Kesenci, 2005).

\subsubsection{Dragons export P\&C to China and final goods to NAFTA and Europe}

Dragons' exports of consumption goods fell abruptly from $28 \%$ of the total in 1993 to $16 \%$ in 2003 while exports of PPC expanded rapidly (from 20\% to 30\%) (Figure 8A). Their exports of consumption goods hardly increased in dollar terms as the production has moved to China. As mentioned above, Japan has turned to China for its imports of consumption goods and that is one of the reason why Dragons' exports to Japan plummeted. Moreover, emerging Asian economies (China and the Tigers) have remained relatively small markets for consumption goods since private consumption has been a relatively weak component of the demand in these economies, as underlined in the recent report by the Asian Development Bank (ADB, 2005). As a result America and Europe have remained major and 
growing markets accounting for more than $60 \%$ of the Dragons' exports of consumption goods (Figure 9D).

Exports of P\&C shifted away from Japan to the Dragons themselselves and China which are now their most important markets.

\subsubsection{Imports switched from Japan to China}

Dragons' imports recorded two important and interconnected changes: a switch from Japan to China and a rapid rise of P\&C. P\&C became the Dragons' most important import category in 2003, accounting for 33\% of imports (against 20\% in 1993), while all other categories of products recorded slight relative decline (Figure 8B). For P\&C, the dramatic decline of Japan as a supplier (from 35\% to 19\% of the Dragons' imports) is explained by two combined factors: first, Japan's exports of P\&C has tended to switch to China; second, an increasing share of the Dragons' supplies have come from other countries, among which the Dragons themselves, the Tigers and China (Figure 10B).

In capital goods also, the share of Japan as a supplier fell dramatically (from 36\% to 23\%) as Japanese exports of this type of goods almost stagnated from 1993 to 2003 (Figure 10C). Dragons' imports of capital goods shifted in favour of China, which increased its share in Dragons' imports from $6 \%$ to $22 \%$. In consumption goods imports, China has become by far the dominant supplier, accounting for $40 \%$ of the total. NAFTA and Japan lost ground while Europe resisted better (Figure 10D).

\section{EMERGING ECONOMIES: THE THREAT OF CHINA'S PRICE COMPETITION}

The above analysis has provided evidence that the major change in East Asian trade has been the declining role of major advanced economies, the US (responsible for $2 / 3$ of NAFTA trade) and Japan. The underlying factor of such a trend has been the massive production facilities created in China, which have led to a redistribution of the final stages of production processes away from advanced economies. The following section shows that Asian emerging economies (Malaysia, Philippines, Thailand) have been less affected by this reorganisation.

\subsection{The Tigers have resisted to China's competition in up-market products}

The Tigers, like other Asian economies have accentuated their vertical specialisation. Their trade is more and more driven by their involvement in the regional segmentation of production processes, as shown by the surge of trade in P\&C which accounted for more than 35\% of their exports and imports in 2003 (against respectively 20\% and 28\% in 1989, (Figure 11). They now carry out most of their trade in P\&C with the Dragons.

In Tigers' overall exports, the share of NAFTA has remained stable and large at about 25\% (Figure 12) and it is still by far their largest market for final good exports, both for consumption and capital goods. (Figure 13). Europe is their second export market for final 
goods, receiving with more than $20 \%$ of these exports. The role of Japan which was their major supplier in 1993 (28\% of their imports) declined abruptly to $20 \%$ in 2003 . Japan lost ground in these markets for P\&C, capital goods and consumption goods, while the other Asian suppliers have strengthened their positions. In the Tigers' trade, China plays an increasing part which remained however below 10\%, much smaller than in the trade of Japan and the Dragons (Figures 12 to 14).

With their production and exports of manufactured goods depending heavily on FDI and contract manufacturing with foreign firms, the Tigers are in potential competition with China both for markets and for foreign capital. Up to now, they have withstood this competition and although their progress in regional and world markets may have been slowed down by China's emergence, they have not been crowded out, neither from Western markets nor from Asian markets. While advanced Asian economies have strong complementarities with China which have boosted investment and trade flows, this is not the case of the Tigers. They have been less attracted by China with which they share similar comparative advantages in labour intensive stages of production. Malaysia, the Philippines and Thailand belong to the second wave of "New industrialised economies", which have built up industrial capacities largely integrated in global or regional production networks.

From 1993 to 2003, the Tigers succeeded in increasing slightly their share in world exports of manufactured products (from 3.0\% to 3.5\%), despite the surge of China's exports in this period (Table 7). Moreover, they have maintained their export share in dynamic and highquality/price products. When looking at their position in world exports of the most dynamic products, that is electronic goods, it stands out that they have not lost market share to China up to 2003. The Tigers were responsible for $10 \%$ of world exports of electronic products in 2003 against $6.6 \%$ in 1993. Their exports to the US slowed down but this was more than compensated by the rise of exports to other partners, mainly China, and also the Dragons and Europe. In this sector, the rise of China implied more trade creation than trade diversion. In world exports of electrical goods, their share was almost stable from 1993 to 2003.

It is often observed that the Tigers are directly exposed to China's competition and that, in order to adapt to this challenge, these countries should move up the quality ladder and improve the technological level of their exports. It may thus be helpful to examine what is their present position in this respects, compared to other Asian countries exporters.

Looking at their position by market segments, it appears that from 1995 to 2003, the Tigers gained share in the upper-market segment of world trade (Figure 15). In this segment, the Tigers increased their market share from $5.6 \%$ to $6.6 \%$ and stand above China $(2.5 \%)$ which has made relatively slow progress. By contrast, in down-market products, the Tigers have slightly lost ground while China's exports have skyrocketed. This tends to confirm that upgrading the quality of their exports is indeed crucial for these emerging countries to

${ }^{6}$ For the classification by quality/price segments, see Appendix 3. 
face the challenge of China's competition. However, the strong presence of China in world exports of low-quality/price products raises many questions.

\subsection{The threat of China's price competition}

\subsubsection{Technological content and quality/price range}

A closer look at the positions of exporters in terms of technological content (according to OECD-Eurostat classification, see Appendix 3) and quality/price range may be helpful to clarify the conditions of competition. The analysis has been conducted in the case of electronic goods ${ }^{7}$ and brings out some interesting findings (Figure 16).

Not surprisingly, Japan's exports display the largest high-tech content, with high-tech goods making half of its exports. The difference in the technological levels of other Asian exports does not reflect the gap in their levels of economic development, as the Tigers, China and the Dragons show relatively similar HT content of exports (between $40 \%$ and $50 \%$ ). This homogeneity reflects the importance of international production networks in electronic industry: the less developed partners (China and the Tigers) have set up export capacities in electronics thanks to foreign direct investment and their trade in electronic goods is carried out by foreign affiliates or by local firms working under contract manufacturing with multinational firms. However, since 1995, a process of differentiation took place: the HT content of Dragons exports has improved rapidly (possibly as a result of the transfer of low-tech production in China) and has tended to catch up with that of Japan. The HT content of the Tigers' exports increased at a relatively slow pace and in the early 2000s it stood below that of China. China had benefited from the building up of large production capacities by foreign firms which accounted for $80 \%$ of the country's HT exports. (see Gaulier, Lemoine and Ünal-Kesenci, 2005).

The positions by quality/price range show a more contrasted picture. Japan's exports are concentrated in the high-quality/price range which makes up about half of its exports in the early 2000s. Dragons' and Tigers' exports have a similar share of high-quality/price products, (1/3 in 2002) but the Tigers' exports are still much more dependent on lowquality/price range while the medium-quality/price range is more important in the Dragons' exports. China is in a very specific position: although the share of high-quality/price products increased, they represented only $8-10 \%$ of its electronic exports in 2003, while low-quality/price products still account for an overwhelming share of its exports (75\%). According to their unit-value, electronic products exported by China are still concentrated in the low-quality/price range. Even in high-tech electronic goods, $70 \%$ of China's exports belong to the low-quality/price range.

Several reasons can be put forwards and combined to explain the importance of the lowquality/price products in China's exports. The first one is that the low price of Chinese exports actually corresponds to a low quality level. Although this may be the case for some

${ }^{7}$ The analysis was conducted for the period 1995 to 2002 (data for 2003 may be less reliable). 
products, it is not likely to be the case for most Chinese exports, especially electronic goods, since they are, for their largest share, produced and exported by foreign affiliates. Another explanation lies in the strong price competitiveness of Chinese exports: thanks to low production costs (and possibly indirect subsidies), producers are able to set price below that of other competitors for the same product. A third reason is the heterogeneity of products: even though the unit value is calculated at the most detailed level of classification (HS6), China's exported products may have different (older) technical standards, no brand name, etc. A last reason may be that the recorded unit-value of the products exported by China corresponds to artificially low prices: this may be the case in intra-firm trade, when the product sold by a foreign affiliate in China to its parent firm is under-priced (transfer prices), in order to diminish the profit recorded in China for fiscal or other reason. This may also be the case when Chinese firms under-invoice their exports in order to circumvent the controls on capital outflows (the difference between the actual and invoiced value of exports is paid outside China), a practice which took some importance at the end of the nineties, in the aftermath of the Asian financial crisis.

\subsubsection{The risk of a downward spiral of cost-competition}

Whatever the relative quality/price level of China's exports compared to other exporters, China's export price declined by more than 2\% a year on average from 1995 to 2003, and by $4 \%$ a year from 1998 to 2003. Decrease in export prices affected all stages of production and all categories of exports (textile \& clothing, electronics, electrical machinery, Table 8). The decline of export prices corresponded to a decline of domestic prices of industrial manufactured products which has started 1997 and stemmed from rapid productivity gains, strong competition and also from over-capacity in many industrial sectors. As mentioned by Steinfeld (2005), China's producers find themselves locked in a downward spiral of intense cost-based competition, primarily with one another (Figure 17).

It is generally recognised that China's exports have helped to keep down the inflationary pressures in world markets of manufactured products. China is a large exporter in a several categories of products (textiles, electrical products, electronics), and has exerted a downward pressure on the international price of these products. This means that countries having the same export specialisation as China have become exposed to the decline of world prices. Indeed, according to data not reported here, since 1995, Thailand, Malaysia, Philippines and India recorded a decline of their export prices of consumption goods even steeper than China. This trend coupled with the rise of oil prices since 2000 has led to a deterioration of terms of trade for many Asian emerging economies (Figure 18B). In 2003, China's strong demand of oil, raw materials and commodities has contributed to the rise of world prices of these products and has thus had a negative impact of the terms of trade of most Asian countries, excepted those well endowed with natural resources (Malaysia). China's emergence may have thus an indirect adverse effect on emerging economies which have followed an export-led growth based on their competitiveness in labour intensive industries. However, China's terms of trade have worsened even more than that of other countries, which may cast some doubts about the sustainability of China's specialisation strategy (Figure 18A). 


\subsubsection{Is China's recent growth strategy sustainable?}

From 1995 to 2003, China's terms of trade fell by 18\%, under the combined effects of falling export prices (-15\%) and rising import prices ( $+3 \%)$. Interestingly, the upward trend in import prices has not come mainly from primary goods but from Parts \& Components, which was its fastest import category over this period (28\% of total exports in 2003). This suggests that China may be trapped in a adverse position in the international segmentation of production processes: it faces a rise in the import prices of intermediate goods necessary to supply its outward-oriented industries, and a fall in the export price of finished goods (Figure 19).

It has to be mentioned that the recent rise in import prices may be exaggerated: in 2003 imports may have been over-invoiced in order to allow speculative inflows of foreign capital into China, since the markets anticipated a re-evaluation of the yuan. However, the rise in import prices of P\&C has been sustained since 1996 and may well reflect a pricing strategy of foreign firms which aims at minimising the profits recorded by their affiliates in China.

More generally China's economic growth since a decade has been mainly driven by investment. In its 2005 Development Outlook, the Asian Development Bank underlined that from 1993 to 2003, a shift occurred in the composition of China's demand, compared with the previous decade: the contribution of household consumption fell, while investment became more important and net exports turned positive. This evolution has been even more accentuated during the recent surge in economic growth since 2003. As noted by the report, most other Asian economies have also failed to implement a growth strategy led by household consumption, which thus appears as the weak link of these economies, India being an exception. China, however, was an extreme case, with private consumption accounting for only $40 \%$ of GDP in 2004. This assessment still holds true despite the fact that revised figures of China's GDP, published in December 2005, have offered a more balanced picture of the economy (with an investment rate down from $44 \%$ to $39 \%$, and an export ratio down from $35 \%$ to $30 \%$ in 2004).

The question is whether China can durably sustain this unbalanced growth. In 2003 and 2004, high growth has been accompanied by rapidly rising industrial profits $(O E C D, 2005)$, but this trend slowed markedly in 2005, as reported by Chinese official statistics and by US affiliate companies in the mainland (Studwell, 2005). This is especially the case in downstream sectors, where firms face strong competition, and have been forced to lower their selling prices, while the recent price rise of energy and raw materials has increased their production costs. Despite the productivity gains and the flexibility of wages, there are indications that the diverging trends in the costs of inputs and the prices of output are squeezing profit margins of manufacturing firms in individual sectors in which the high level of investment (both domestic and foreign) has led to a situation of over-capacity. In 2005 , in the car industry, profits fell by $29 \%$, in electronic industry by $3.3 \%$. 
It is unlikely that Chinese exports can go on expanding at the rate shown over the last three years (+35\% a year from 2003 to 2005, according to China's Customs Statistics) without provoking new trade disputes with other actors of the world economy. Moreover, China's rapid trade expansion makes its economy more vulnerable to fluctuations in the global business cycle (and especially to a US demand overturn) and to international trade disputes. To ensure a sustainable and high economic growth, China has little choice but to return to a more balanced growth in favour of domestic consumption. Increase in wages and employment together with the extension of the social security system should support household consumption (Blanchard and Giavazzi, 2005).

\section{CONCLUSION}

The study has brought to the fore important changes in Asian trade. The following findings deserve to be emphasised:

Asian trade is increasingly driven by the international segmentation of production processes within the region, a trend which has been accelerated by the rise of China as a major partner in production networks.

Asian trade is more and more centred on China but the region records growing trade surpluses in final goods with the rest of the world. The emergence of China has not (yet?) created an autonomous engine for regional economic growth.

The positions of advanced economies, mainly the US and Japan, in Asian trade have been considerably weakened. This results from several intricate factors. One is the regionalisation process which has accelerated trade within NAFTA and within Asia. Another one is the move of large volumes of production to low cost sites (Mexico, China).

As China has become an export plate-form for multinational firms, the driving force of Japan's trade shifted from exporting final goods to North America and Europe towards exporting components to China, and from importing final goods from America, Europe and the Dragons towards importing these goods from China. The Dragons' trade also switched away from Japan and NAFTA and towards China.

The sourcing strategies of multinational firms have led to a reorganisation of production which has weakened trade between the advanced economies but up to now has not severely affected the position of Asian emerging economies (Malaysia, Philippines, Thailand) in international trade.

However, the surge of China's exports since 2003, associated with the continuous decline in export prices, suggests the risk of a downward spiral of cost-competition, as China's prices exert a downward pressure on international prices of manufactured products. 
China's Emergence and the Reorganisation of Trade Flows in Asia

The question is raised of the sustainability of China's growth strategy during the last decade, as it has led to a deterioration of China's terms of trade and to the multiplication of trade disputes. China's capacity to switch to a more balanced growth, led by domestic consumption, is a crucial factor for the future of the Asian and world economy. 


\section{REFERENCES}

ADB (Asian Development Bank) (2005), Asian Development Outlook.

BlanCHARD O., F. GiAvazZI (2005), "Rebalancing Growth in China: A Three-Handed Approach”, Massachusetts Institute of Technology, Department of Economics, Working Paper 05-32, November.

Broda C. \& D.E. Weinstein (2004), “Globalization and the Gains from Variety” NBER Working Paper 10314.

DiEWERT W.E. (1976), “Exact and Superlative Index Numbers”, Journal of Econometrics 4, 114-145. Reprinted in Essays in Index Number Theory, (Vol. 1), W.E. Diewert and A.O. Nakamura, eds, Elsevier Science Publishers, Amsterdam, 1993.

ERNST D. (2004), "Global Production Networks in East Asia Electronic Industry and Upgrading Perspective in Malaysia”, in Yusuf et aili.

GAulier G., F. LEMOINE \& D. ÜNAL-KeSENCI (2005), “China’s Integration in East Asia: Production Sharing, FDI \& High-Tech Trade”, CEPII Working Paper, n²005-09, June.

GAulier G., F. LEMoine \& D. ÜNAL-KeSENCi (2005), “China: A Workshop of the World and a Market For Europe”, La Lettre du CEPII, n²45, May.

GAUliER G., S. JeAN \& D. ÜnAL-KesEnCI (2004), "Regionalism and the Regionalisation of International Trade”, CEPII Working Paper, n²004-16, November.

LALL S., M. BDALADEJO \& J. ZHANG (2004), "Mapping Fragmentation: Electronics and Automobiles in East Asia and Latin America”, QEH Working Paper Series, Number 115, February.

Lemoine F. \& D. ÜnAL-Kesenci (2004), “Assembly Trade and Technology Transfer: the Case of China”, World Development, vol. 32, n 5, pp. 829-850.

OECD (2005), Economic Surveys, China. Volume 2005/13- September.

STEINFELD E. D. (2004), “Chinese Entreprise Development and the Challenge of Global Integration”, in Yusuf, Shahid M et alii.

STUDWELl J. (2005), “Multinational profits. Let me down slow”, China Economic Quartely, volume 9, Issue 4,

Sturgeon T.J. \& R.K. Leister (2004), “The New Global Supply Base: New Challenges for Local Suppliers in East Asia”, in Yusuf, Shahid M et alii. 
China's Emergence and the Reorganisation of Trade Flows in Asia

THE ECONOMIST (2005), “From T-shirts to T-bonds”, July 30"

WeISS J. (2004), "Peoples's Republic of China and its Neighbours: Partners or Competitors for Trade and Investment?”, ADBI Research Paper Series, n 59, August.

Yusuf S., M.A. AltaF \& K. NABeShima (editors) (2004), “Global Production Networking and Technological Change in East Asia”, The World Bank, Washington DC. 


\section{TABLES}

Table 1

Firms with Foreign Capital (FFC) in China's Trade with Selected Partners 2002 (\% Total Flows)

\begin{tabular}{lrrrrrrrr}
\hline & World & EU-15 & USA & Japan & Hongkong & Singapore & Korea & Taiwan \\
\hline \multicolumn{1}{c}{ China's Total Exports } & $\mathbf{1 0 0}$ & $\mathbf{1 0 0}$ & $\mathbf{1 0 0}$ & $\mathbf{1 0 0}$ & $\mathbf{1 0 0}$ & $\mathbf{1 0 0}$ & $\mathbf{1 0 0}$ & $\mathbf{1 0 0}$ \\
FFC Total Exports & 52 & 50 & 58 & 62 & 63 & 65 & 49 & 57 \\
FFC Processed Exports & 41 & 40 & 48 & 47 & 54 & 54 & 35 & 45 \\
$\quad$ China's Total Imports & $\mathbf{1 0 0}$ & $\mathbf{1 0 0}$ & $\mathbf{1 0 0}$ & $\mathbf{1 0 0}$ & $\mathbf{1 0 0}$ & $\mathbf{1 0 0}$ & $\mathbf{1 0 0}$ & $\mathbf{1 0 0}$ \\
FFC Total Imports & 54 & 49 & 48 & 67 & 63 & 61 & 63 & 67 \\
FFC Imports for & 32 & 12 & 21 & 39 & 53 & 36 & 41 & 49 \\
Processing & & & & & & &
\end{tabular}

Source: Chinas Customs Statistics, authors’ calculations.

Table 2

Share of Asian Countries in World Trade of Manufactured Products

\begin{tabular}{lrrrrrrr}
\hline & \multicolumn{3}{c}{ Exports } & & \multicolumn{3}{c}{ Imports } \\
& 1993 & 2003 & Change & & 1993 & 2003 & Change \\
\cline { 6 - 8 } Japan & 12.5 & 7.5 & -5.0 & & 5.1 & 4.0 & -1.1 \\
Dragons & 8.9 & 8.7 & -0.2 & & 10.3 & 8.6 & -1.7 \\
Tigers & 3.0 & 3.8 & 0.7 & & 3.1 & 2.6 & -0.5 \\
China & 3.8 & 7.7 & 3.9 & & 3.0 & 5.2 & 2.2 \\
India & 0.7 & 0.9 & 0.2 & & 0.5 & 0.8 & 0.3 \\
Other Asia & 1.4 & 1.6 & 0.2 & 1.6 & 1.3 & -0.3 \\
Oceania & 1.3 & 1.0 & -0.3 & & 1.7 & 1.6 & -0.1 \\
& & & & & & \\
Asia-Oceania & 31.7 & 31.3 & -0.4 & 25.2 & 24.0 & -1.2 \\
World & 100.0 & 100.0 & 0.0 & 100.0 & 100.0 & 0.0 \\
\hline \hline
\end{tabular}

Source: CEPII-BACI data base, authors' calculations. 
China's Emergence and the Reorganisation of Trade Flows in Asia

Table 3

Distribution of Intra-Asian Trade by Major Partners Manufactured Products (in \%)

\begin{tabular}{|c|c|c|c|c|c|c|c|c|}
\hline $\begin{array}{l}\text { Importers } \\
\text { Exporters }\end{array}$ & Japan & Dragons & Tigers & China & India & $\begin{array}{l}\text { Other } \\
\text { Asia }\end{array}$ & Oceania & Asia-Oceaénia \\
\hline \multicolumn{9}{|c|}{2003} \\
\hline Japan & & 10.8 & 3.7 & 6.1 & 0.3 & 1.1 & 1.3 & 23.3 \\
\hline Dragons & 3.6 & 8.6 & 4.3 & 11.5 & 0.8 & 2.0 & 1.1 & 31.9 \\
\hline Tigers & 2.6 & 5.6 & 1.4 & 2.0 & 0.3 & 1.0 & 0.6 & 13.4 \\
\hline China & 6.3 & 11.8 & 1.4 & & 0.3 & 1.1 & 1.0 & 21.9 \\
\hline India & 0.2 & 0.6 & 0.2 & 0.3 & & 0.4 & 0.1 & 1.7 \\
\hline Other Asia & 1.1 & 1.2 & 0.6 & 0.5 & 0.2 & 0.2 & 0.3 & 4.1 \\
\hline Oceania & 0.7 & 0.8 & 0.4 & 0.4 & 0.2 & 0.2 & 1.0 & 3.7 \\
\hline Asia-Oceania & 14.3 & 39.5 & 12.0 & 20.8 & 2.0 & 6.1 & 5.4 & 100.0 \\
\hline \multicolumn{9}{|c|}{1993} \\
\hline Japan & & 18.6 & 6.5 & 4.3 & 0.3 & 2.3 & 2.4 & 34.5 \\
\hline Dragons & 5.6 & 9.3 & 4.8 & 6.5 & 0.6 & 2.6 & 1.2 & 30.6 \\
\hline Tigers & 2.5 & 5.3 & 0.7 & 0.4 & 0.0 & 0.6 & 0.4 & 10.0 \\
\hline China & 3.4 & 8.9 & 0.4 & & 0.1 & 0.7 & 0.5 & 13.9 \\
\hline India & 0.4 & 0.6 & 0.2 & 0.1 & & 0.3 & 0.1 & 1.5 \\
\hline Other Asia & 1.4 & 1.6 & 0.4 & 0.3 & 0.0 & 0.2 & 0.2 & 4.1 \\
\hline Oceania & 1.4 & 1.6 & 0.6 & 0.2 & 0.0 & 0.3 & 1.2 & 5.4 \\
\hline Asia-Oceania & 14.6 & 45.9 & 13.6 & 11.8 & 1.2 & 7.0 & 5.9 & 100.0 \\
\hline
\end{tabular}

Source: CEPII-BACI data base, authors' calculations.

Table 4

Asian Trade in Parts and Components (P\&C) (\% World Trade)

\begin{tabular}{|c|c|c|c|c|c|c|}
\hline \multicolumn{7}{|c|}{2003} \\
\hline \begin{tabular}{l}
\multicolumn{1}{c}{ Importers } \\
Exporters
\end{tabular} & IEs* & China & Other Asia & Oceania & Asia-Oceania & World \\
\hline Japan \& NIEs* & 13.2 & 4.9 & 0.7 & 0.3 & 19.2 & 30.7 \\
\hline China & 3.1 & & 0.1 & 0.0 & 3.3 & 6.0 \\
\hline Other Asia & 0.4 & 0.0 & 0.0 & 0.0 & 0.5 & 0.8 \\
\hline Oceania & 0.1 & 0.0 & 0.0 & 0.1 & 0.2 & 0.3 \\
\hline Asia-Oceania & 16.8 & 5.0 & 0.9 & 0.4 & 23.1 & 37.9 \\
\hline \multirow[t]{2}{*}{ World } & 23.3 & 7.6 & 1.5 & 1.0 & 33.4 & 100.0 \\
\hline & \multicolumn{4}{|c|}{1993} & & \\
\hline Japan \& NIEs* & 12.5 & 1.2 & 0.8 & 0.5 & 15.1 & 31.6 \\
\hline China & 0.6 & & 0.1 & 0.0 & 0.7 & 1.1 \\
\hline Other Asia & 0.1 & 0.0 & 0.0 & 0.0 & 0.2 & 0.4 \\
\hline Oceania & 0.1 & 0.0 & 0.0 & 0.1 & 0.2 & 0.4 \\
\hline Asia-Oceania & 13.4 & 1.3 & 0.9 & 0.6 & 16.2 & 33.5 \\
\hline World & 21.1 & 2.1 & 1.8 & 1.5 & 26.5 & 100 \\
\hline
\end{tabular}

- Dragons and Tigers.

Source: CEPII-BACI data base, authors' calculations. 
Table 5

Changes in Intra- and Inter-Regional trade in Manufactured Products from 1993 to 2003 (in percent points of World trade)

\begin{tabular}{|c|c|c|c|c|c|c|c|c|c|}
\hline Exporters & \begin{tabular}{|c} 
Japan \& \\
NIEs \\
\end{tabular} & China & $\begin{array}{l}\text { Other } \\
\text { Asia }\end{array}$ & Oceania & World & $\begin{array}{c}\text { Asia- } \\
\text { Oceania }\end{array}$ & $\begin{array}{l}\text { Rest of } \\
\text { the World }\end{array}$ & Europe & America \\
\hline Japan \& NIEs* & -1.6 & 1.4 & -0.1 & -0.1 & -4.4 & -0.5 & -4.0 & -0.7 & -2.8 \\
\hline China & 1.1 & 0.0 & 0.1 & 0.1 & 3.9 & 1.3 & 2.6 & 1.1 & 1.2 \\
\hline Other Asia & -0.1 & 0.1 & 0.1 & 0.0 & 0.4 & 0.1 & 0.3 & 0.1 & 0.1 \\
\hline Oceania & -0.2 & 0.0 & 0.0 & -0.0 & -0.3 & -0.2 & -0.1 & 0.0 & -0.0 \\
\hline World & -3.3 & 2.2 & -0.0 & -0.1 & 0.0 & -1.2 & 1.2 & 2.6 & -1.8 \\
\hline Asia-Oceania & -0.8 & 1.5 & 0.0 & -0.0 & -0.4 & 0.7 & -1.1 & 0.5 & -1.5 \\
\hline Rest of the World & -2.5 & 0.7 & -0.1 & -0.1 & 0.4 & -1.9 & 2.3 & 2.1 & -0.3 \\
\hline Europe** & -0.8 & 0.2 & -0.1 & 0.0 & 2.0 & -0.6 & 2.7 & 2.3 & 0.3 \\
\hline America & -1.6 & 0.2 & -0.1 & -0.1 & -3.7 & -1.6 & -2.1 & -0.9 & -0.8 \\
\hline
\end{tabular}

- Dragons and Tigers.

**EU-25, EFTA \& Other Eastern European countries.

Source: CEPII-BACI data base, authors' calculations.

Table 6

World Manufacturing Trade Matrix by Major Area (in Percent of World Manufacturing Trade)

\begin{tabular}{|c|c|c|c|c|c|}
\hline \multicolumn{6}{|l|}{2003} \\
\hline Exporter & Asia-Oceania & Europe-Africa & America & Total & Intra-area share \\
\hline Asia-Oceania & 16 & 8 & 8 & 32 & 49 \\
\hline Europe-Africa & 5 & 39 & 6 & 50 & 78 \\
\hline America & 3 & 4 & 11 & 18 & 58 \\
\hline Total & 24 & 51 & 25 & 100 & \\
\hline Intra-area share & 65 & 76 & 43 & & \\
\hline \multicolumn{6}{|l|}{1993} \\
\hline & Importer & & & & \\
\hline Exporter & Asia-Oceania & Europe-Africa & America & Total & Intra-area share \\
\hline Asia-Oceania & 15 & 8 & 10 & 32 & 47 \\
\hline Europe-Africa & 6 & 35 & 5 & 46 & 76 \\
\hline America & 5 & 6 & 11 & 22 & 52 \\
\hline Total & 26 & 48 & 26 & 100 & \\
\hline Intra-area share & 59 & 72 & 43 & & \\
\hline
\end{tabular}

Source: CEPII-BACI data base, authors' calculations. 
China's Emergence and the Reorganisation of Trade Flows in Asia

Table 7 - Changes in World Trade from 1993 to 2003 (in \% points)

\begin{tabular}{|c|c|c|c|c|c|c|c|c|c|c|}
\hline \multicolumn{10}{|c|}{ Electronics* } & \multirow[b]{2}{*}{$\begin{array}{c}\text { Share in } \\
\text { world exports, } \\
2003 \\
\end{array}$} \\
\hline $\begin{array}{l}\text { Importers } \\
\text { Exporters }\end{array}$ & Japan & Dragons & Tigers & China & India & $\begin{array}{l}\text { Other } \\
\text { Asia }\end{array}$ & EEA & NAFTA & World & \\
\hline Japan & & -2.5 & -0.4 & 0.8 & -0.0 & -0.3 & -2.8 & -5.8 & -11.6 & 10.5 \\
\hline Dragons & 0.3 & 1.0 & 0.3 & 2.7 & 0.2 & -0.1 & -0.0 & -2.3 & 1.8 & 19.3 \\
\hline Tigers & 0.4 & 0.7 & 0.4 & 0.9 & 0.0 & 0.1 & 0.7 & 0.2 & 3.5 & 10.1 \\
\hline China & 1.0 & 2.3 & 0.5 & & 0.1 & 0.2 & 2.4 & 2.8 & 9.7 & 12.5 \\
\hline India & 0.0 & -0.0 & 0.0 & 0.0 & & 0.0 & 0.0 & 0.0 & 0.1 & 0.1 \\
\hline Other Asia & 0.1 & 0.1 & 0.1 & 0.0 & 0.0 & 0.0 & 0.1 & 0.0 & 0.4 & 1.0 \\
\hline World & 3.5 & 5.4 & 2.0 & 6.9 & 0.5 & 0.6 & 16.8 & 0.8 & 0.0 & 100.0 \\
\hline $\begin{array}{l}\text { Share in world } \\
\text { imports in } 2003\end{array}$ & 5.4 & 17.6 & 5.0 & 8.4 & 0.6 & 1.8 & 33.0 & 21.6 & 100.0 & \\
\hline \multicolumn{11}{|c|}{ Electrical machinery** } \\
\hline $\begin{array}{l}\text { Importers } \\
\text { Exporters }\end{array}$ & Japan & Dragons & Tigers & China & India & $\begin{array}{l}\text { Other } \\
\text { Asia }\end{array}$ & EEA & NAFTA & World & $\begin{array}{c}\text { Share in } \\
\text { world exports, } \\
2003 \\
\end{array}$ \\
\hline Japan & & -1.7 & -1.0 & 0.8 & -0.0 & -0.5 & -1.0 & -2.5 & -6.7 & 9.4 \\
\hline Dragons & -0.3 & -0.5 & -0.3 & 1.0 & 0.0 & -0.2 & -0.3 & -0.9 & -1.6 & 8.3 \\
\hline Tigers & 0.1 & -0.2 & 0.1 & 0.2 & 0.0 & 0.0 & 0.1 & -0.0 & 0.3 & 3.4 \\
\hline China & 1.0 & 1.4 & 0.3 & & 0.0 & 0.0 & 1.8 & 1.6 & 6.8 & 11.6 \\
\hline India & 0.0 & -0.0 & -0.0 & 0.0 & & 0.0 & 0.1 & 0.1 & 0.2 & 0.5 \\
\hline Other Asia & 0.2 & 0.1 & 0.1 & 0.0 & 0.0 & -0.1 & 0.1 & 0.1 & 0.6 & 1.5 \\
\hline World & 2.1 & 1.6 & -0.2 & 5.0 & 0.5 & 0.4 & 30.0 & 11.1 & 0.0 & 100.0 \\
\hline $\begin{array}{l}\text { Share in world } \\
\text { imports in } 2003\end{array}$ & 4.0 & 10.8 & 3.2 & 6.7 & 0.6 & 2.3 & 38.3 & 23.7 & 100.0 & \\
\hline \multicolumn{11}{|c|}{ All manufactured products } \\
\hline $\begin{array}{l}\text { Importers } \\
\text { Exporters }\end{array}$ & Japan & Dragons & Tigers & China & India & $\begin{array}{l}\text { Other } \\
\text { Asia }\end{array}$ & EEA & NAFTA & World & $\begin{array}{c}\text { Share in } \\
\text { world exports, } \\
2003 \\
\end{array}$ \\
\hline Japan & & -1.0 & -0.3 & 0.2 & -0.0 & -0.3 & -0.8 & -1.7 & -4.4 & 6.5 \\
\hline Dragons & -0.3 & -0.1 & -0.1 & 0.7 & 0.0 & -0.0 & 0.1 & -0.6 & -0.4 & 7.8 \\
\hline Tigers & -0.0 & 0.0 & 0.1 & 0.2 & 0.0 & 0.1 & 0.1 & 0.0 & 0.5 & 3.5 \\
\hline China & 0.3 & 0.4 & 0.1 & & 0.0 & 0.1 & 0.9 & 1.0 & 3.2 & 6.9 \\
\hline India & -0.0 & 0.0 & 0.0 & 0.0 & & 0.0 & 0.0 & 0.0 & 0.2 & 0.9 \\
\hline Other Asia & -0.3 & -0.2 & 0.0 & 0.1 & 0.1 & -0.0 & 0.0 & 0.0 & -0.4 & 3.2 \\
\hline World & 2.0 & 2.0 & 0.6 & 3.3 & 0.9 & 1.2 & 31.9 & 8.7 & 0.0 & 100.0 \\
\hline $\begin{array}{l}\text { Share in world } \\
\text { imports in } 2003\end{array}$ & 4.7 & 8.3 & 2.5 & 5.0 & 1.1 & 3.0 & 41.4 & 21.1 & 100.0 & \\
\hline
\end{tabular}

*ISIC 30 (Office machinery \& computers), 32 (Radio, TV \& communication equipment), 33 (Medical, precision

\& optical instruments)

** ISIC 31

Source: CEPII-BACI data base, authors' calculations. 
Table 8

Evolution of World Prices and of China's Export Prices

by ISIC Manufacturing Branches, 1997-2003

(Annual Average in \%)

\begin{tabular}{lcc}
\hline & $\begin{array}{c}\text { China's Export } \\
\text { Price index }\end{array}$ & $\begin{array}{c}\text { World } \\
\text { Price index }\end{array}$ \\
\hline Publishing, printing \& reproduction of recorded media & -7.2 & 1.3 \\
Chemicals \& chemical products & -4.9 & 0.4 \\
Non-metallic mineral products & -4.5 & -0.2 \\
Textiles & -4.4 & -1.6 \\
Wood \& of products & -4.2 & -2.8 \\
Basic metals & -4.0 & -0.5 \\
Electrical machinery & -3.9 & -1.8 \\
Tobacco products & -3.7 & 5.1 \\
Machinery & -3.6 & -0.2 \\
Rubber \& plastic & -3.6 & -1.2 \\
Wearing apparel & -3.5 & -1.3 \\
Food products \& beverages & -3.4 & -0.7 \\
Other transport equipment & -2.9 & 1.2 \\
Leather & -2.7 & -0.6 \\
Medical, precision \& optical instruments & -2.2 & 1.3 \\
Motor vehicles, trailers \& semi-trailers & -2.2 & 1.6 \\
Metal products & -2.1 & 0.0 \\
Pulp, paper \& paper products & -2.0 & 0.6 \\
Radio, TV \& communication equipment & -1.9 & 0.2 \\
Furniture; manufacturing n.e.c. & -1.3 & -0.7 \\
Office machinery \& computers & -0.2 & -2.7 \\
Coke, refined petroleum products \& nuclear fuel & 8.3 & 7.0 \\
\hline
\end{tabular}

*Price indices are calculated by unit values of products at the 6 digit level of HS classification (national currency for China and US\$ for the World).

Source: CEPII-BACI data base, authors' calculations. 


\section{FIGURES}

Figure 1

Composition of Asia-Oceania's International Trade by Production Stages

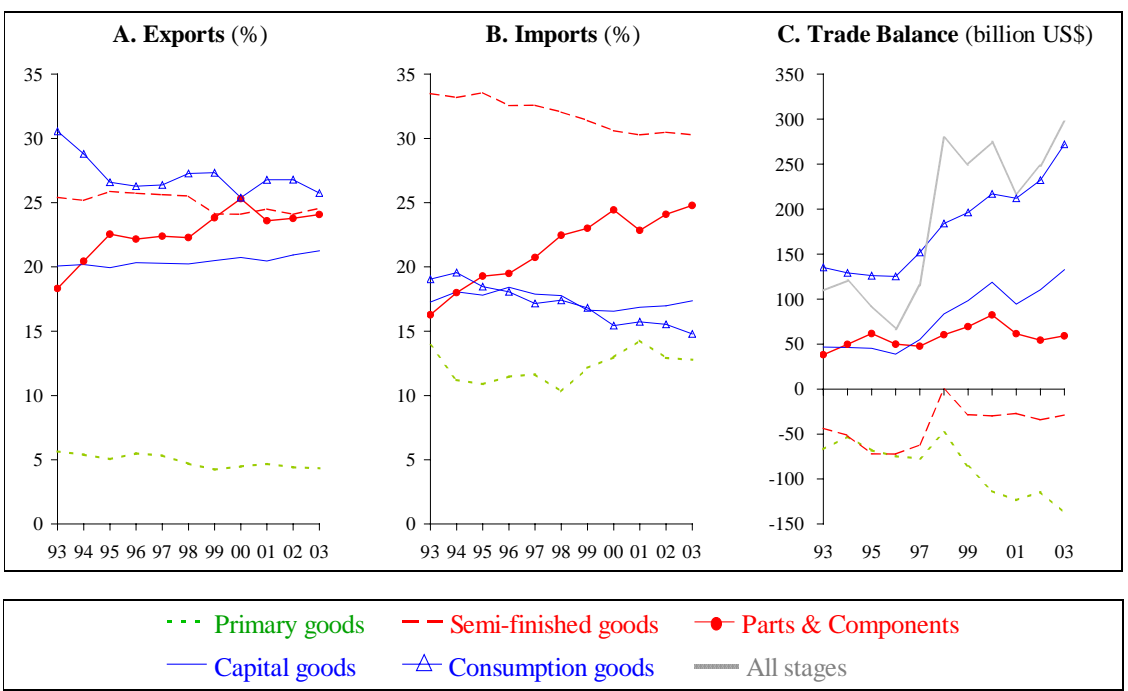

Source: CEPII-BACI data base, authors’ calculations.

Figure 2

Share of Asia-Oceania in World Trade by Production Stages

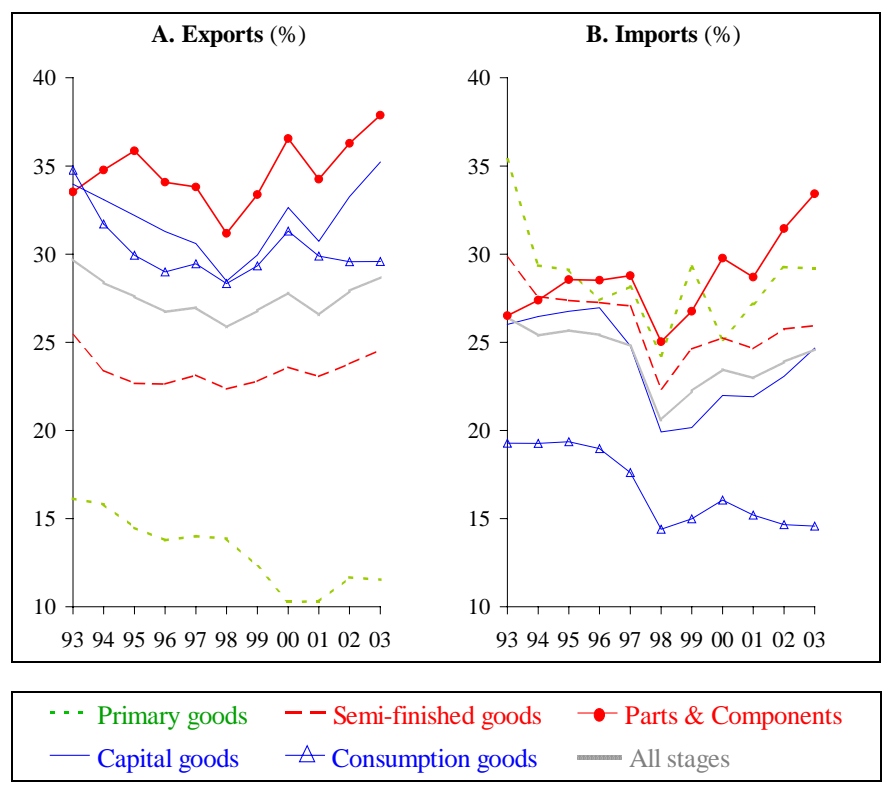

Source: CEPII-BACI data base, authors’ calculations. 
Figure 3

International Trade of Japan by Selected Partners (\%)

ALL PRODUCTS

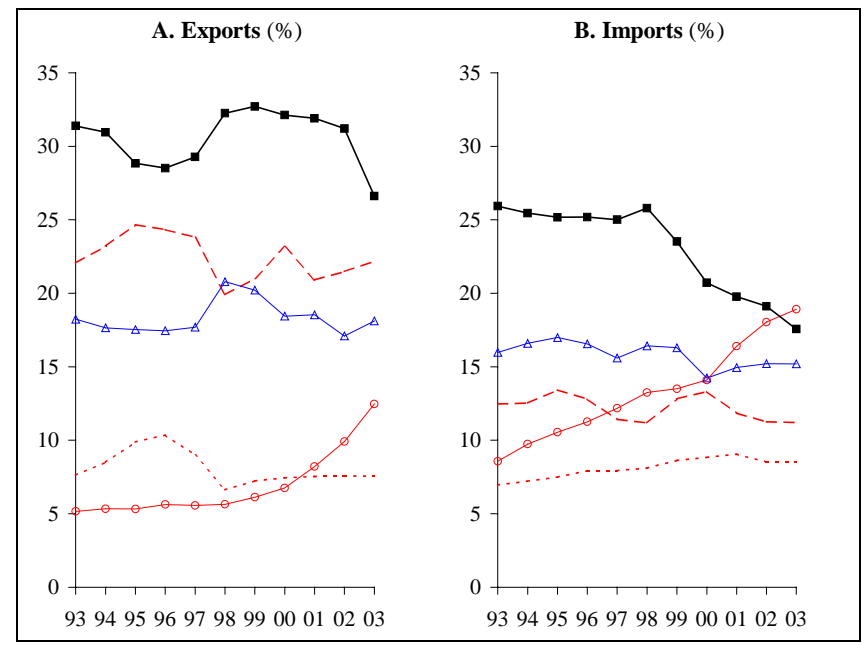

-- Dragons $\cdots$. Tigers $\odot$ China $\triangle$ European Eco. Area $\rightarrow$ NAFTA

Source: CEPII-BACI data base, authors’ calculations.

Figure 4

International Trade of Japan by Production Stages (\%)
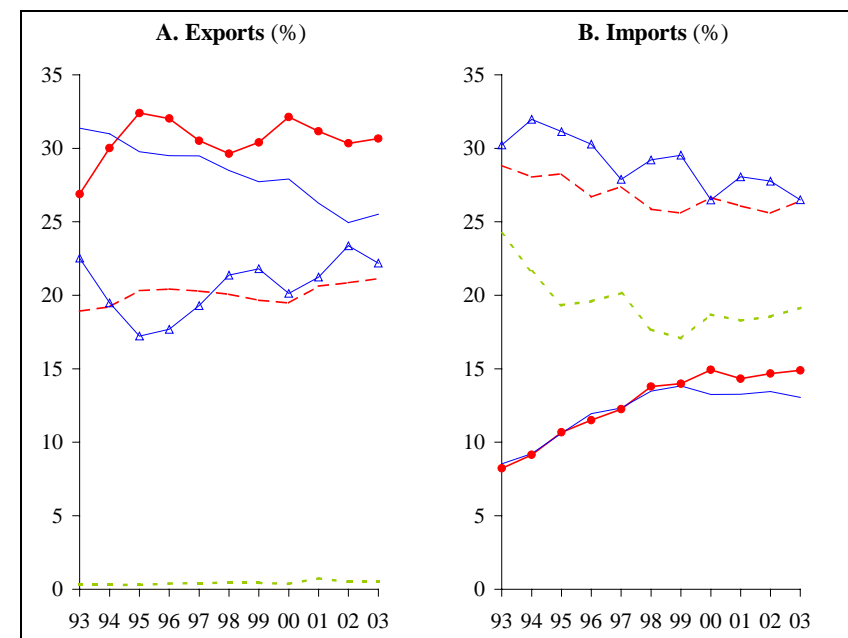

- - Primary goods - - Semi-finished goods $\bullet$ Parts \& Components

- Capital goods $\triangle$ Consumption goods $\quad$ All stages

Source: CEPII-BACI data base, authors' calculations. 
Figure 5

Exports of Japan by Selected Partners and Production Stages (in \% of Production Stage Exports)
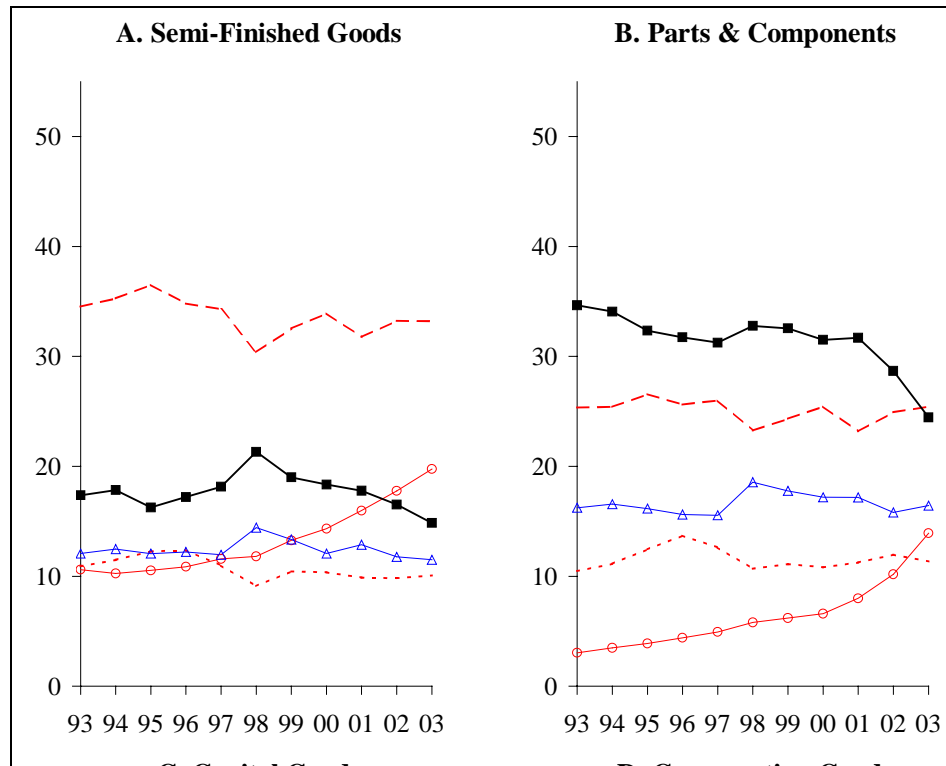

C. Capital Goods

D. Consumption Goods
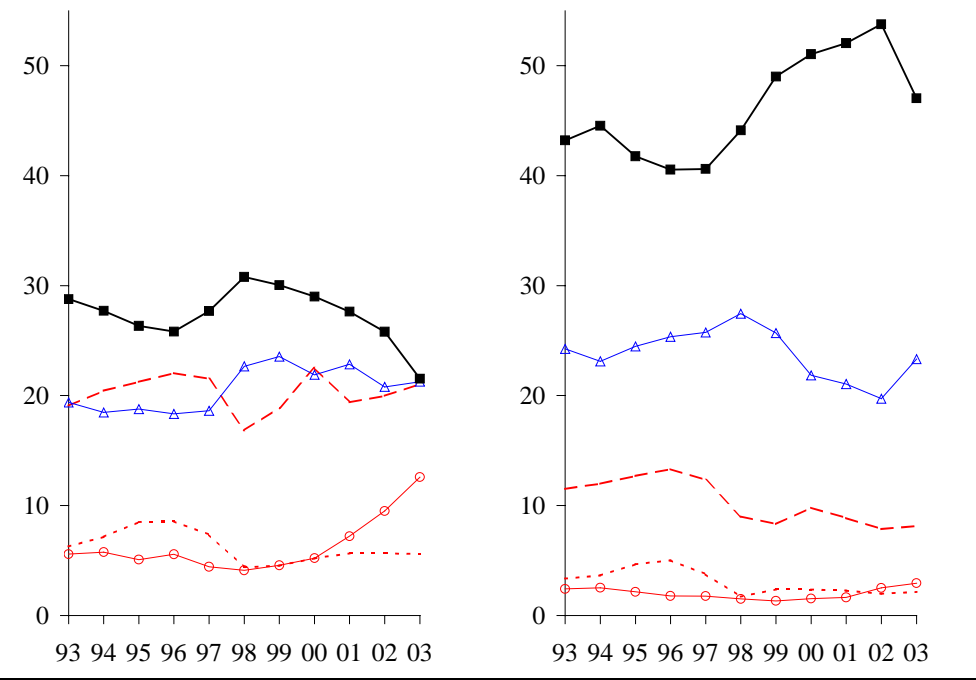

-- Dragons $\cdots$... Tigers $\bigcirc$ China $\triangle$ European Eco. Area

Source: CEPII-BACI data base, authors’ calculations. 
Figure 6

Imports of Japan by Selected Partners and Production Stages (in \% of Production Stage Imports)

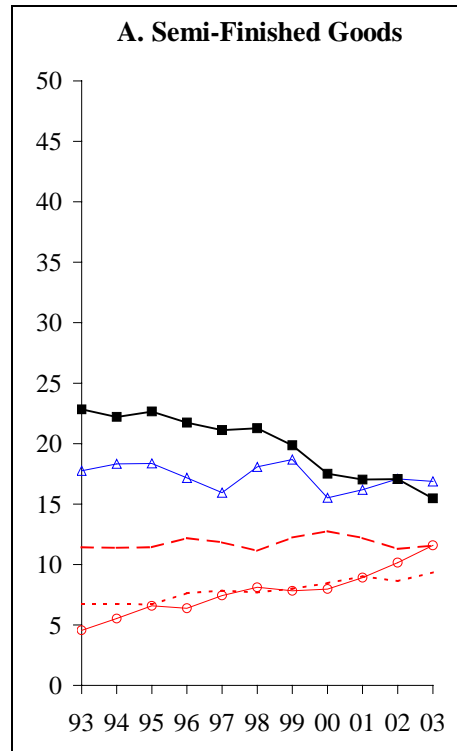

B. Parts \& Components
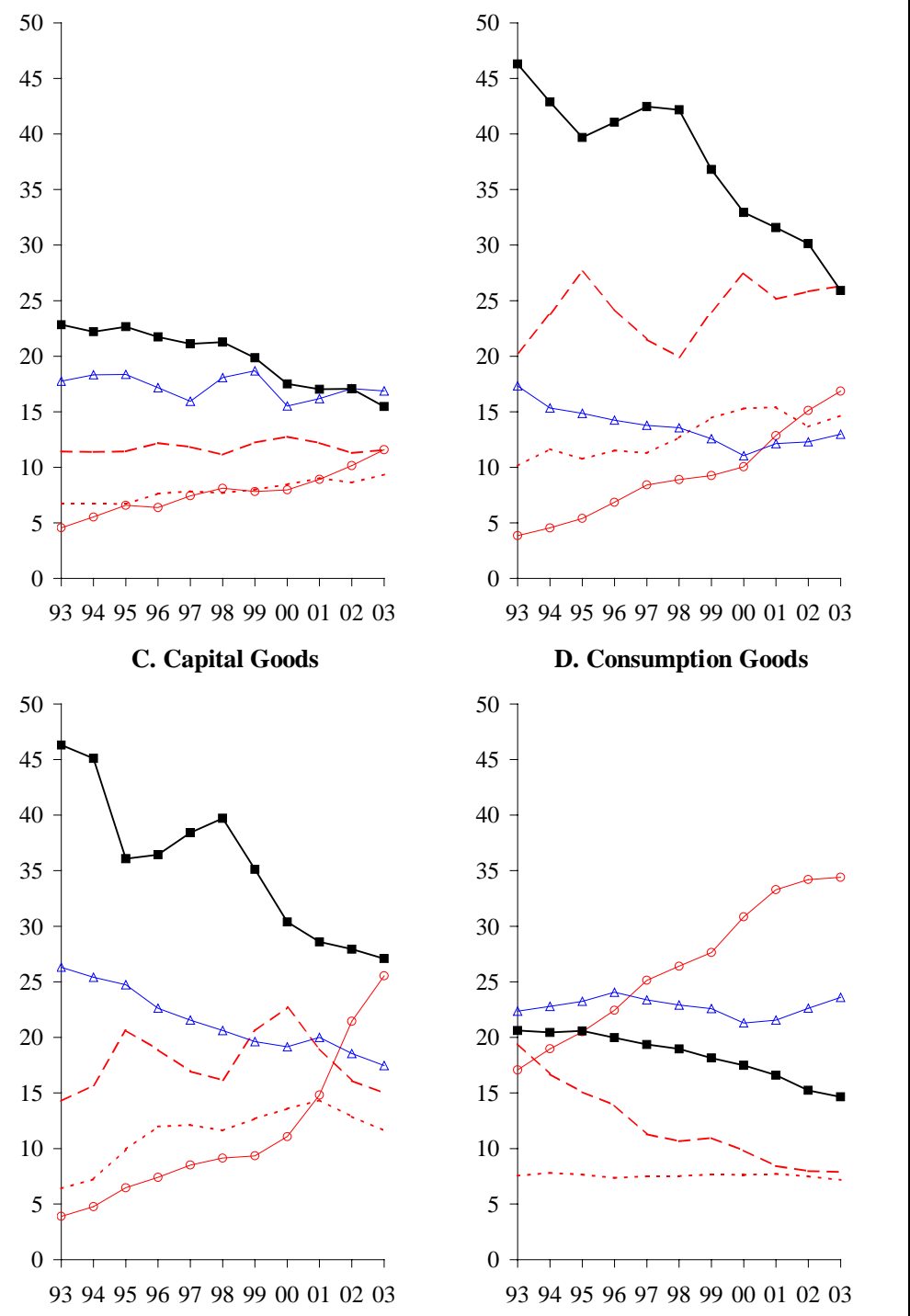

-- Dragons $\cdots$... Tigers $\bigcirc$ China $\triangle$ European Eco. Area

NAFTA

Source: CEPII-BACI data base, authors' calculations. 
Figure 6bis

Distribution by Selected Partners of Japan's Trade in Electronics (in \%)

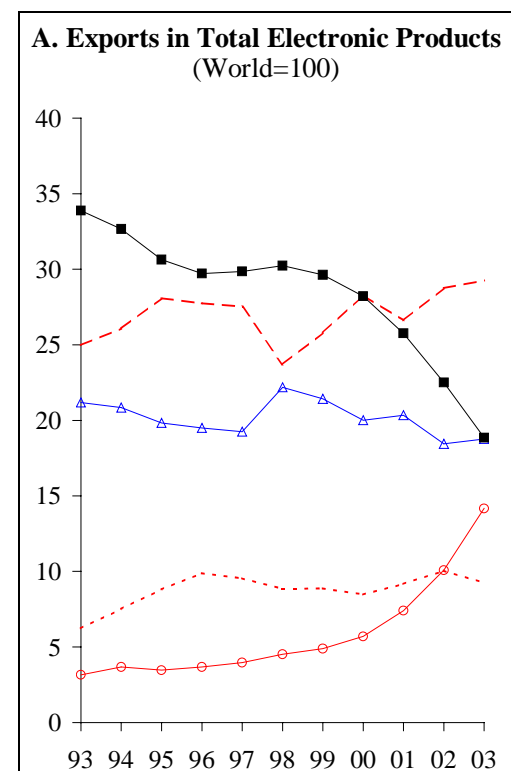
B. Exports in Electronic Parts \& Components (World=100)

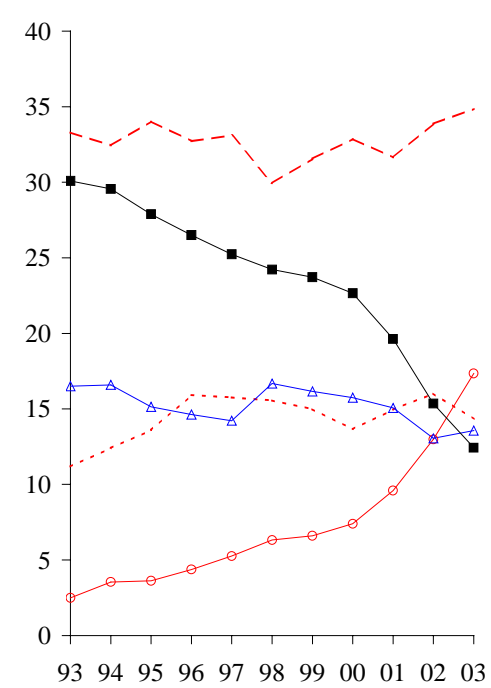

C. Imports in Total Electronic Products (World=100)

D. Imports in Electronic Capital Goods

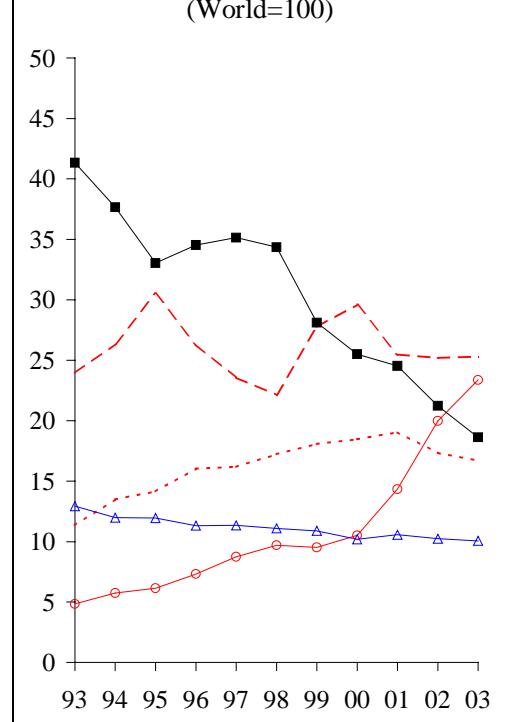

(World=100)

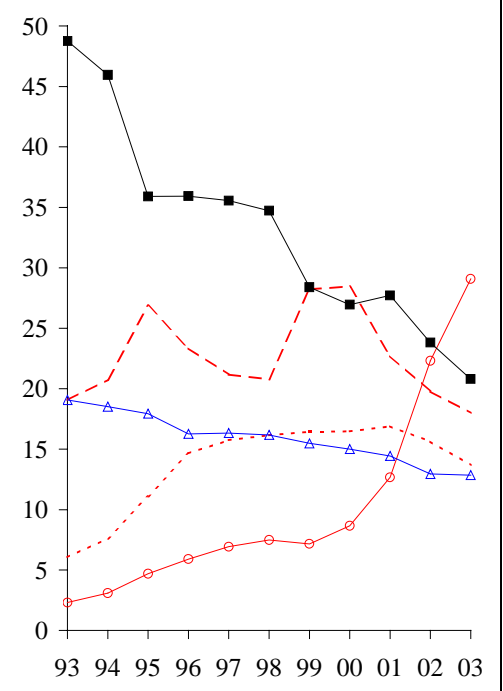

- - Dragons .... Tigers $\odot$ China $\triangle$ European Eco. Area

- NAFTA

Source: CEPII-BACI data base, authors' calculations. 
Figure 7

International Trade of Dragons by Selected Partners (\%) ALL PRODUCTS

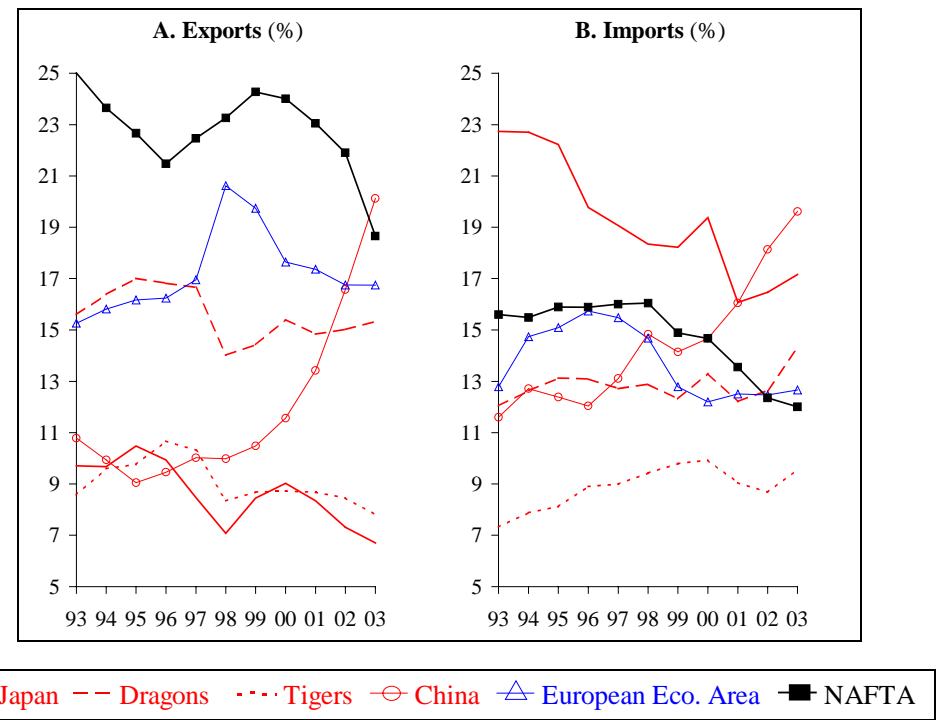

Source: CEPII-BACI data base, authors' calculations.

Figure 8

International Trade of Dragons by Production Stages (\%)

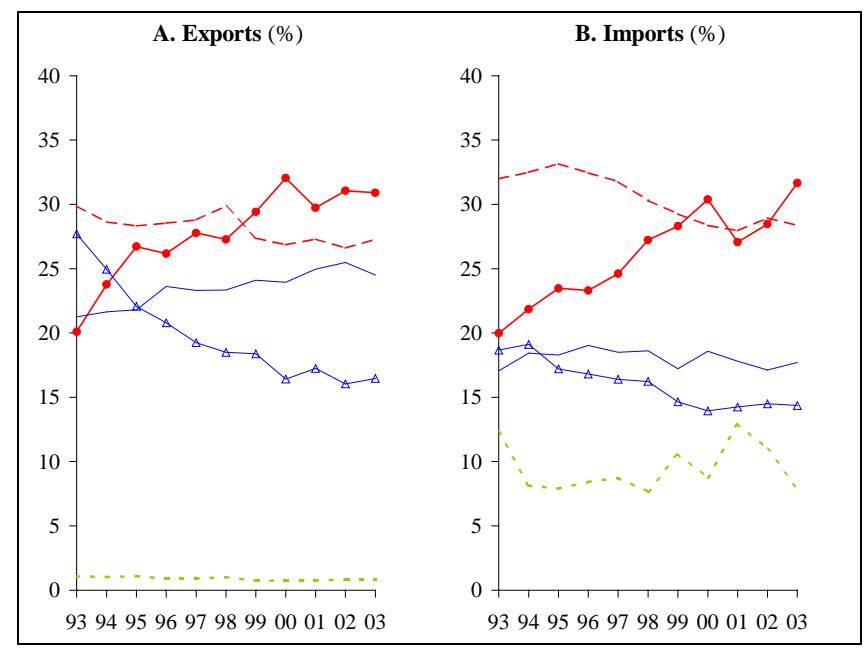

.. - Primary goods $\quad--$ Semi-finished goods $\multimap$ Parts \& Components

Source: CEPII-BACI data base, authors' calculations. 
China's Emergence and the Reorganisation of Trade Flows in Asia

Figure 9

Exports of Dragons by Selected Partners and Production Stages (in \% of Production Stage Exports)

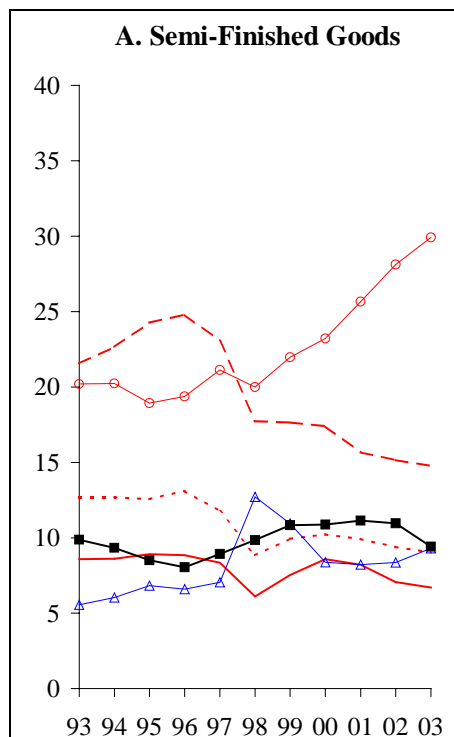

B. Parts \& Components

C. Capital Goods
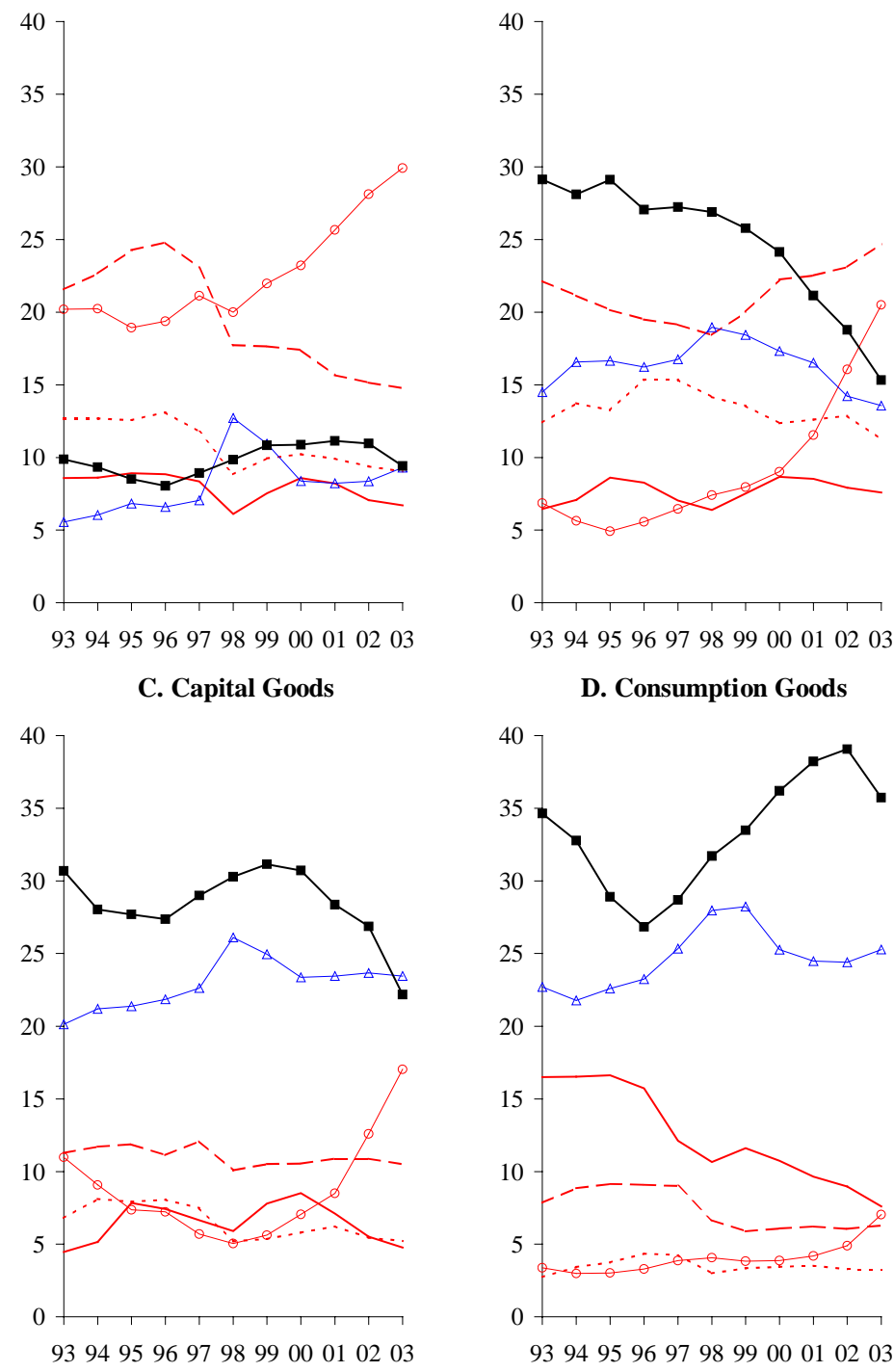

D. Consumption Goods

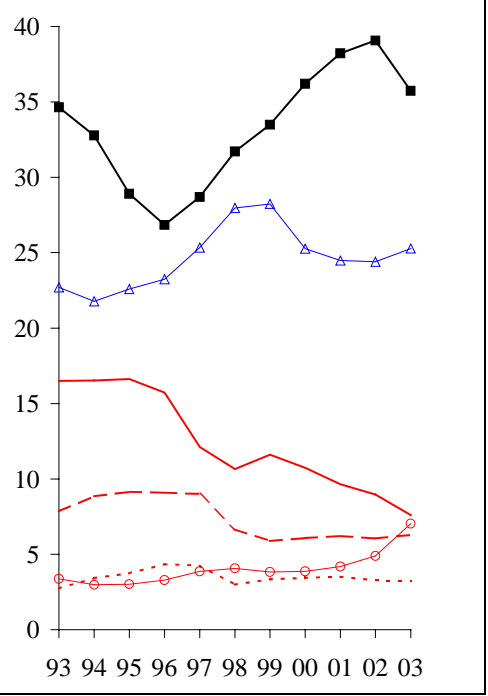

- Japan -- Dragons $\cdots$ Tigers $\odot$ China $\triangle$ European Eco. Area

Source: CEPII-BACI data base, authors' calculations. 
Figure 10

Imports of Dragons by Selected Partners and Production Stages

(in \% of Production Stage Imports)

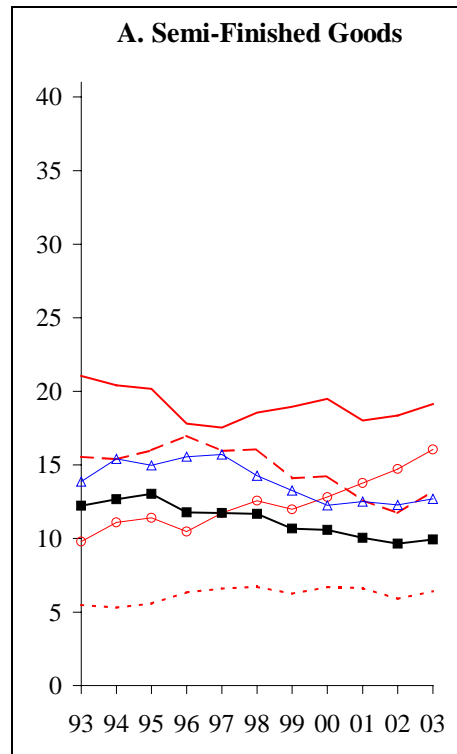

B. Parts \& Components

C. Capital Goods
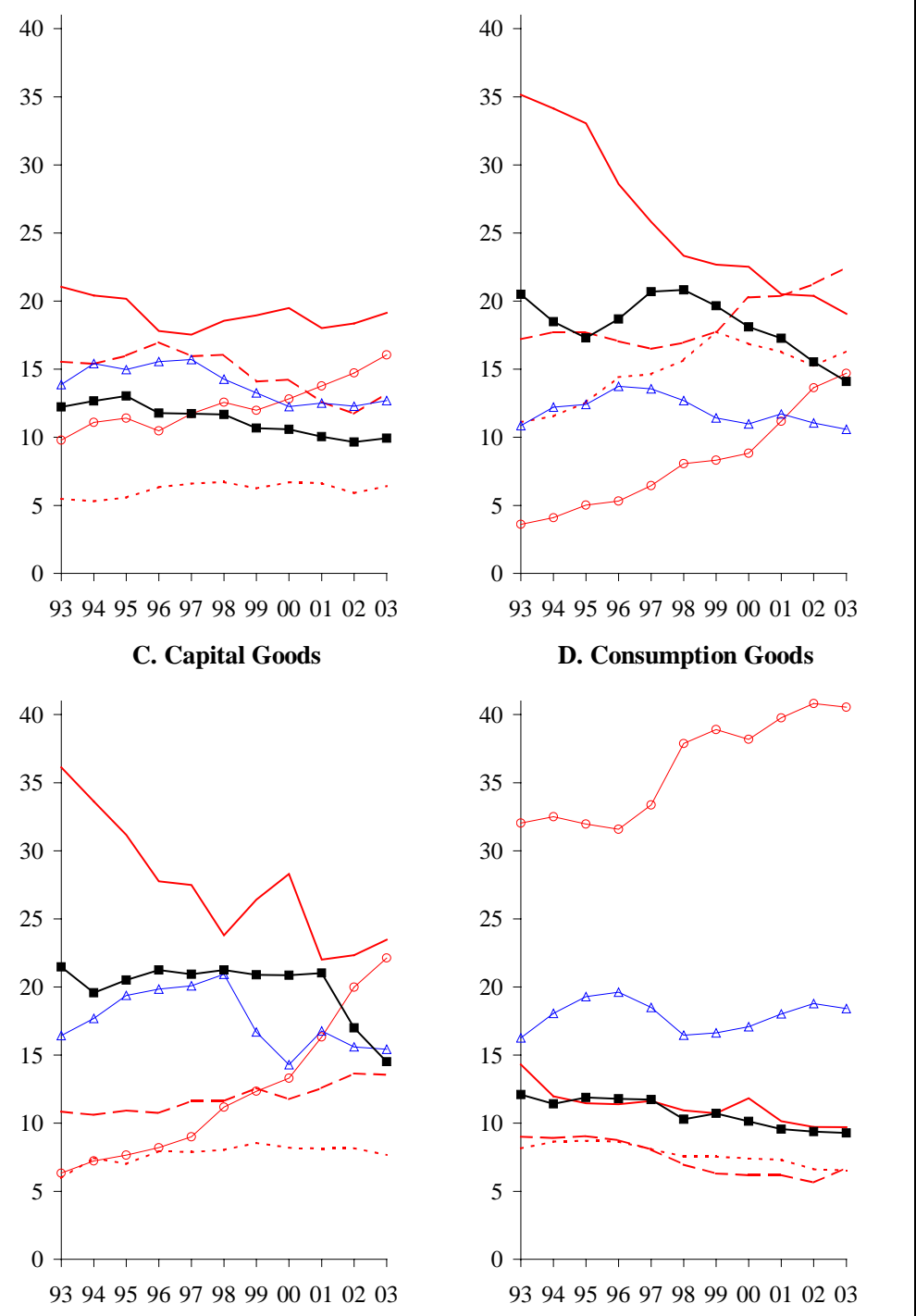

- Japan - Dragons -... Tigers $\bigcirc$ China $\triangle$ European Eco. Area

NAFTA

Source: CEPII-BACI data base, authors' calculations. 
Figure 11

International Trade of Tigers by Production Stages (\%)
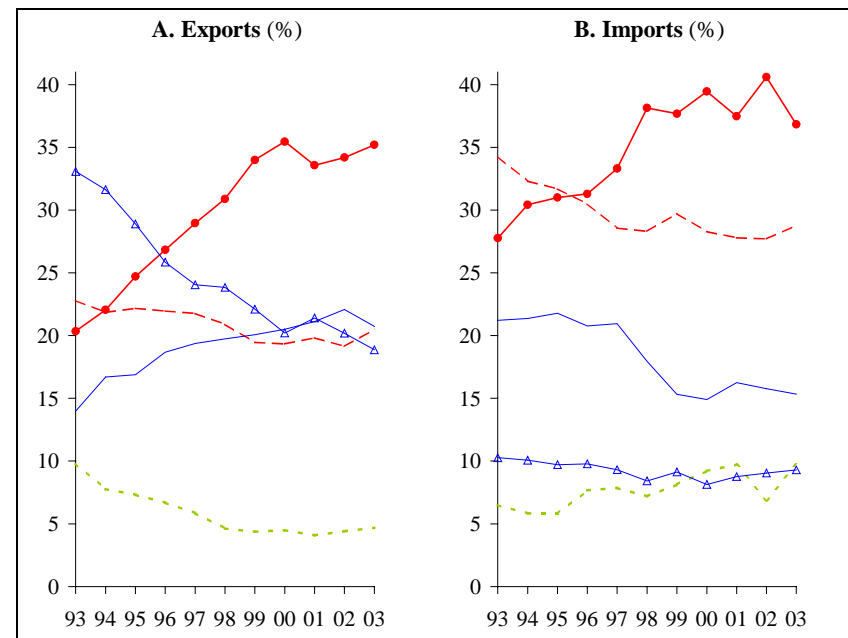

- - Primary goods $\quad-$ - Semi-finished goods $\multimap$ Parts \& Components

— Capital goods $\triangle$ Consumption goods $\quad$ All stages

Source: CEPII-BACI data base, authors' calculations.

Figure 12

International Trade of Tigers by Selected Partners (\%) ALL PRODUCTS

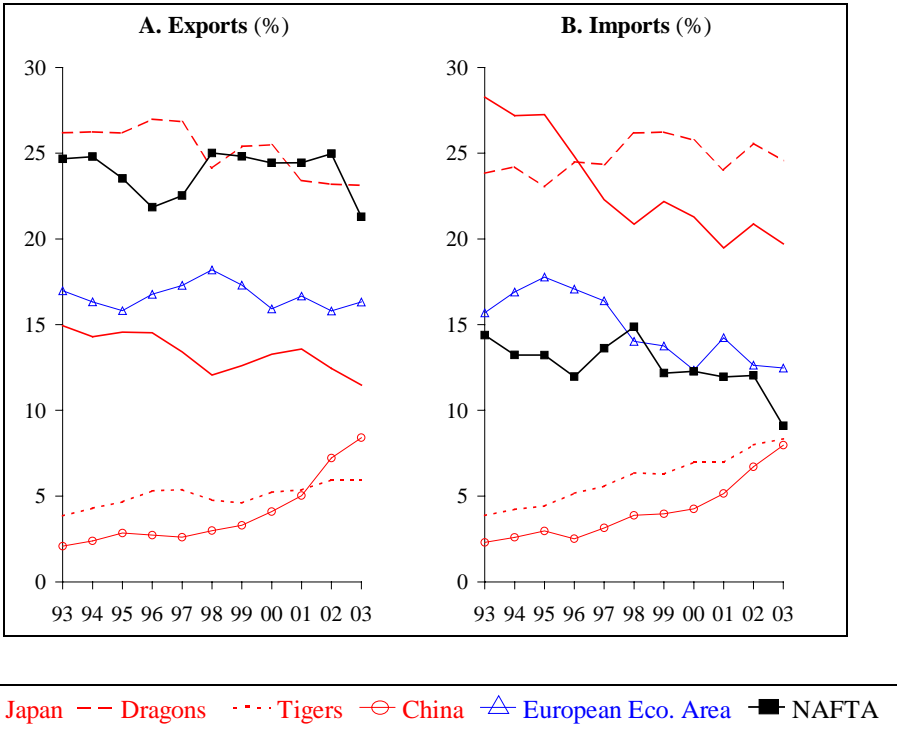

Source: CEPII-BACI data base, authors' calculations. 
Figure 13

Exports of Tigers by Selected Partners and Production Stages (in \% of Production Stage Exports)

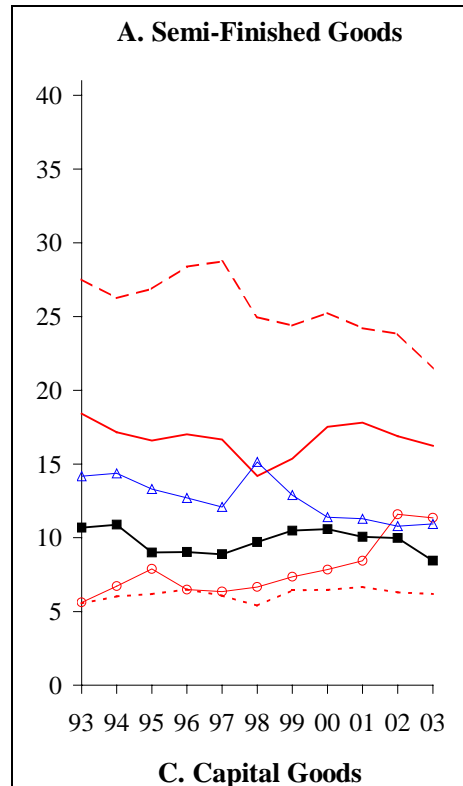

B. Parts \& Components
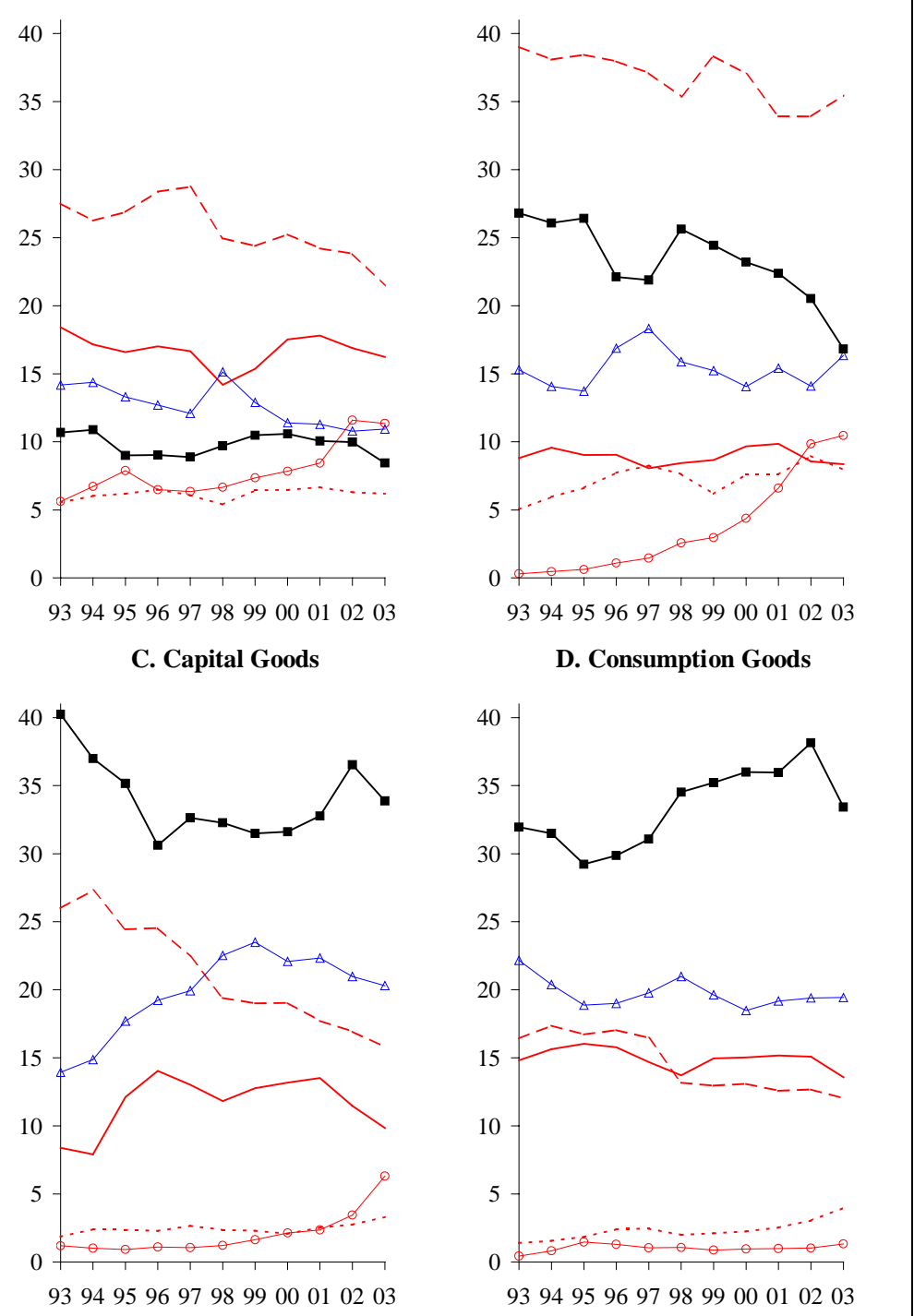

— Japan -- Dragons $\quad \cdots$... Tigers $\bigcirc$ China $\triangle$ European Eco. Area

Source: CEPII-BACI data base, authors' calculations. 
China's Emergence and the Reorganisation of Trade Flows in Asia

Figure 14

Imports of Tigers by Selected Partners and Production Stages (in \% of Production Stage Imports)

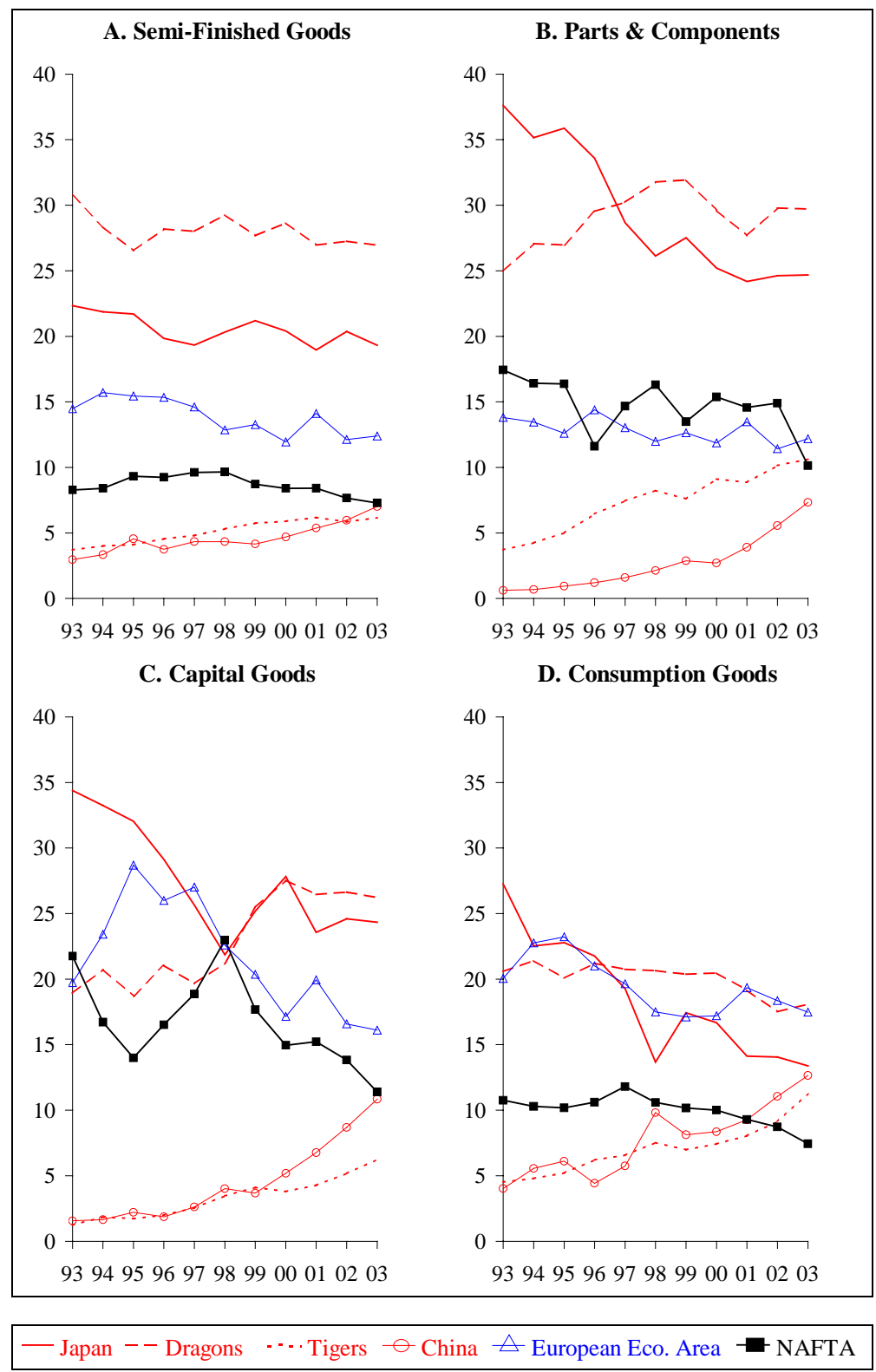

Source: CEPII-BACI data base, authors’ calculations. 
Figure 15

Asian Country Share in World Exports by “Quality/Price” Range (\% world exports in the respective range)

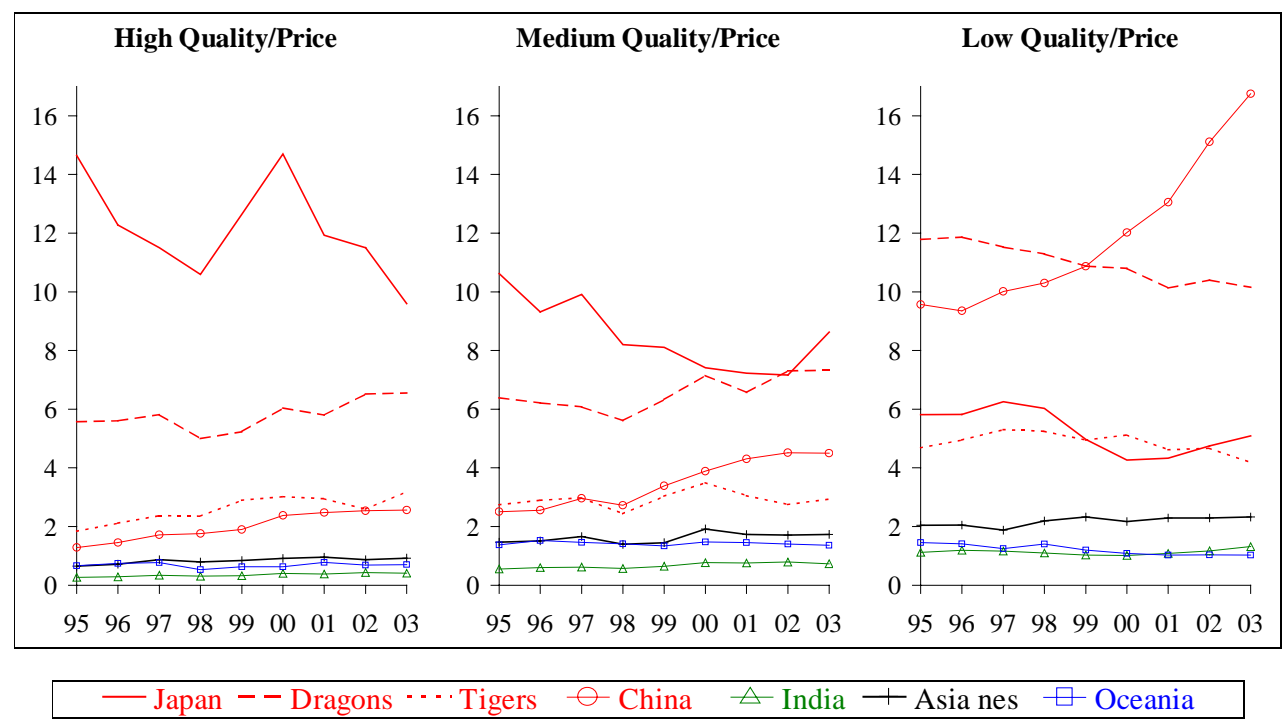

Source: CEPII-BACI data base, authors' calculations. 
Figure 16

Asian Exports of Electronic Products, by “Quality/Price” Range \& Technological Content (\% Country's Exports in Electronics)

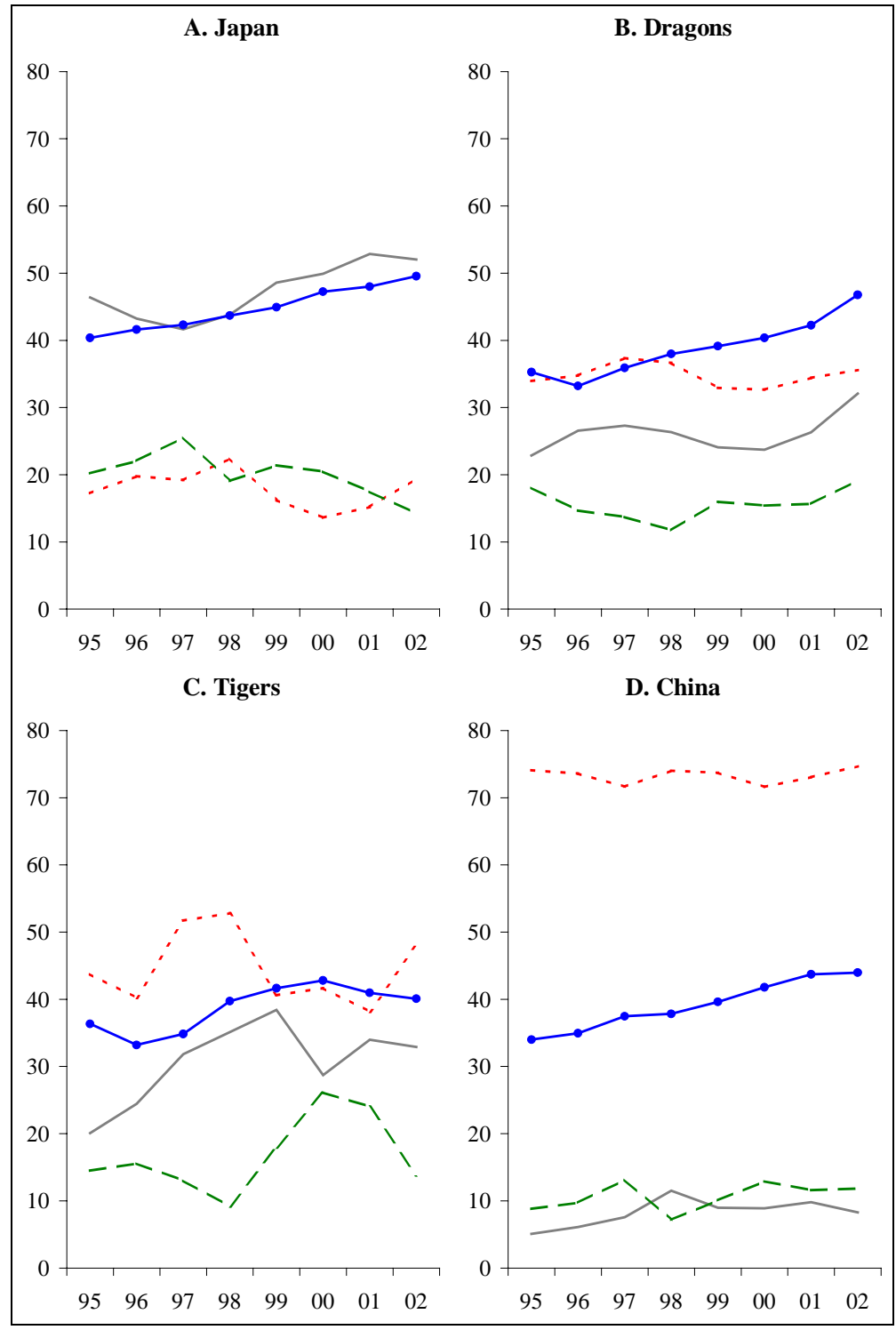

— High-quality $\quad$ - - Medium-quality $\quad$---Low-quality $\rightarrow$ High-tech/Total

Source: CEPII-BACI data base, authors' calculations. 
Figure 17

China: Ex-Factory Prices of Manufactured Products 1997-2004 (1997=1)

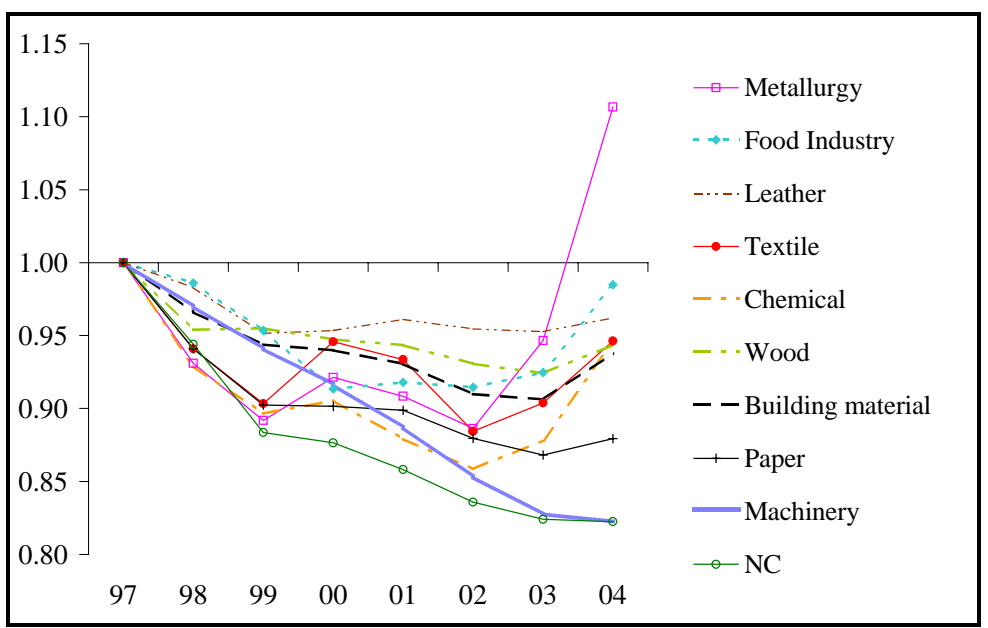

Source: National Bureau of Statistics, Beijing.

Figure 18

Evolution of Terms of Trade* 1995-2003 (Index 1995=1)

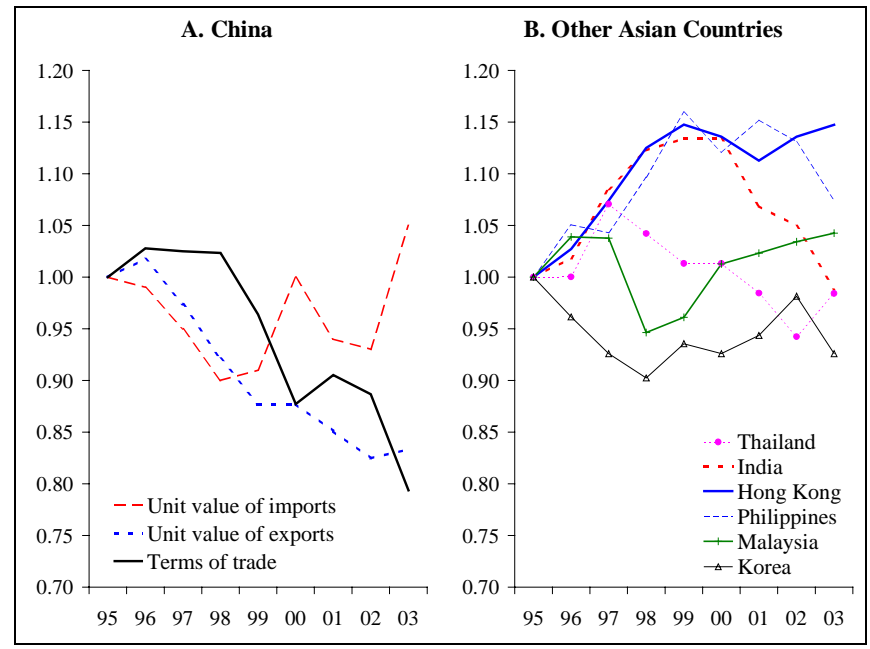

Price indices are calculated by unit values of products at the 6 digit level of HS classification (national currencies). Source: CEPII-BACI data base, authors' calculations. 
China's Emergence and the Reorganisation of Trade Flows in Asia

Figure 19

China: Export and Import Prices by Production Stages* 1995-2003 (Index 1995=1)

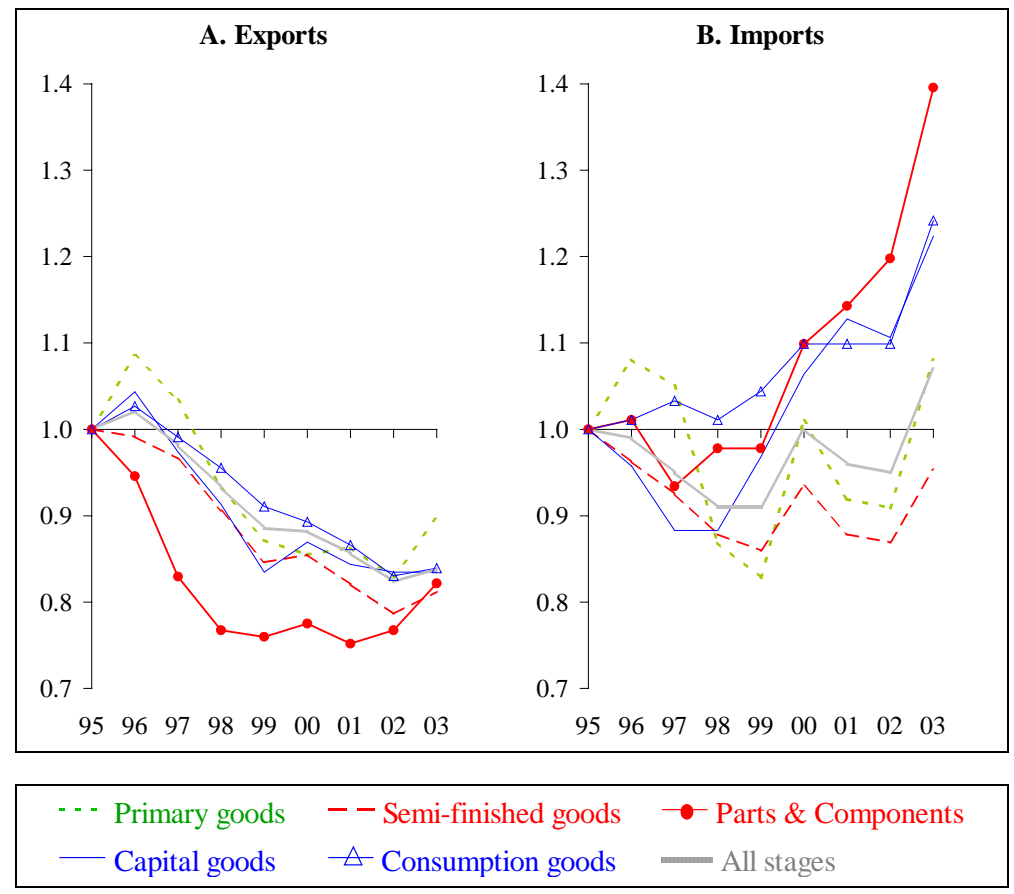

Price indices are calculated by unit values of products (in USD) at the 6 digit level of HS classification.

Source: CEPII-BACI data base, authors' calculations. 


\section{APPENDICES}

\section{APPENDIX 1 - GEOGRAPHICAL CLASSIFICATION}

\begin{tabular}{lll}
\hline ASIA-OCEANIA & $\begin{array}{l}\text { Japan } \\
\text { Dragons }\end{array}$ & $\begin{array}{l}\text { Hongkong, Singapore, South Korea, } \\
\text { Taiwan }\end{array}$ \\
\cline { 2 - 3 } & Tigers & Malaysia, Philippines, Thailand \\
\cline { 2 - 3 } & $\begin{array}{l}\text { China } \\
\text { India }\end{array}$ & \\
& $\begin{array}{l}\text { Asia NES } \\
\text { Oceania }\end{array}$ & \\
\hline EUROPE-AFRICA & European Economic Area & EU-25 + EFTA \\
\cline { 2 - 3 } & EU Periphery & $\begin{array}{l}\text { Other Eastern Europe, Mediterranean } \\
\text { Countries, CIS }\end{array}$ \\
\cline { 2 - 3 } & Sub Saharan Africa \& Gulf & USA, Canada, Mexico \\
\hline AMERICA & NAFTA & Brazil, Argentina, Uruguay, Paraguay \\
\cline { 2 - 3 } & Mercosur & \\
\cline { 2 - 3 } & Other America & \\
\hline NES & &
\end{tabular}




\section{APPENDIX 2 - BACI: AN ANALYTICAL DATABASE ON INTERNATIONAL TRADE}

International trade statistics can only used to carry out detailed studies related to recent developments in economic theory, at the cost of extensive, fastidious work on treating data from numerous, heterogeneous sources. To meet these difficulties, the CEPII has constructed a database on international trade which brings together and renders consistent various levels of analyses and classifications, drawing on the most detailed information available. The particular goal is to put forward a characterisation of trade flows in terms of trade types (one-way trade, cross-trade in similar products, cross-trade in vertically differentiated products), product ranges, technological levels and stages of production.

BACI draws on the UN's trade database COMTRADE and renders consistent trade flow by reconciling information reported by the exporter and the importer (when both are available). This harmonisation of mirror flows is done for value and quantities. The latter statistics being converted before into tons when necessary, making possible the computation of homogeneous unit values.

A detailed description is available in pdf format in the CEPII website: http://www.cepii.fr/anglaisgraph/bdd/baci.htm. 


\section{APPENDIX 3 - CLASSIFICATION BY “QUALITY-PRICE” RANGE}

To test the hypothesis that holds that regional integration is followed by a specialisation along a quality range, we need to measure the quality of traded goods. We use unit value ${ }^{8}$ as a proxy for quality, and define three ranges: low, medium and high quality. For each HS6 product and for each year, we compute the world unit value average (noted $\overline{U V}$ ). We then classify each flow:

- Flows with unit values verifying UV-25\%, UV+25\% belong to the medium range, along with the last decile of ] $\min , \overline{U V}-25 \%]$ and the first decile of $[\overline{U V}+25 \%, \max [$.

- The first nine deciles of ]min, $\overline{U V}-25 \%]$ are considered low range.

- The last nine deciles of $[\overline{U V}+25 \%, \max [$ are considered high range.

This method permits to take into account the high variability of unit values, and to have a significant share of trade in the medium range.

It is theoretically possible to classify any flow using this procedure, as long as the unit value is available. However, it appears wise to avoid associating flows with ranges when it was not possible to ascertain the validity of such a classification. Thus, when the variance of the unit value was too high for a product, flows were not classified.

\section{A. TRADE PRICE INDEX:}

Values (V) and quantities (Q) are taken from BACI (see above).

Unit value ratios, UVR $=\mathrm{V}$ (USD) / Q (tons), are computed for each trade flow : from exporter (i) to importer (j) in 6-digit product Harmonised System (k) at time t.

Changes in UVR (dlnUVR=lnUVRt-lnUVRt-1) are aggregated by means of weighted median in order to computed price indexes for countries or sectors (possibly country * sector).

$\operatorname{dln} \mathrm{Pt}=$ weighted median of dlnUVRt

weight: $w_{i, j, k, t}=0.5 \cdot\left(\frac{V_{i, j, k, t-1}}{V_{t-1}}+\frac{V_{i, j, k, t}}{V_{t}}\right)$

where $V_{t}=\sum_{i, j, k} V_{i, j, k, t}$

${ }^{8}$ Unit values in the BACI database are corrected so as not to take into account transportation costs. 
dln Pt are chained to compute P time-serie. Pt= Pt-1*exp(dln Pt).

Example: for a country i at time t, dln Pit is the weighted median of dln UVRijkt across dimensions $\mathrm{j}$ and $\mathrm{k}$.

Notes: before computing weighted medians the 5\% lowest and 5\% highest UVR changes are removed (for each country and year is the price index is computed for a country as in the example). The idea is to get rid of extreme observations, numerous given the low quality of UVR data. Only trade flows with a value superior to USD10,000 and a quantity superior to 2 tons are used.

\section{B. WEIGHTING SCHEME:}

Weight are those used in the Tornqvist index, making our index a geometric median index rather than a geometric mean index, with weights taking into account year $t$ and $t-1$ and thus accounting for structural changes. Diewert (1976) shows that the Tornqvist price index measures the change in a cost or expenditure function that has the translog functional form, and that the Tornqvist quantity index measures the change in a translog utility or production function. In that cases the Tornqvist index is an ideal index (superlative index).

Each index, computed from weighted median price change, is based to 1 at year 2000.

Index are reported in USD, domestic currency or SDR.

\section{LIMITS:}

Only flows with available value and quantity (weight) for two consecutive years can be used. Notice that this is a less severe limitation when data are harmonised (one partner declaring quantities is enough). The method is only valid when there is a large number of elementary UVR available. Therefore, results are not reliable for small countries and/or sectors.

Quantities in tons may not be an adequate measure of volume for various products (electronics, etc).

Change in quality are attributed to prices.

New as well as disappearing trade flows are not taken into account (which can be problematic for some emerging countries). In the words of Broda and Weinstein (2004), our price indexes are conventional price indexes rather than exact price indexes, they do not take into account changes in variety. 


\section{APPENDIX 4 - \\ CLASSIFICATION BY PRODUCTION STAGE ACCORDING TO THE BEC}

In this study, the data from China's Customs statistics available at 6 digits of Harmonised System were aggregated according to the BEC classification (Broad Economic Categories of the United Nations of production stages). The BEC reclassifies the Standard International Trade Classification (SITC, Rev. 3) headings on the basis of the principal use of the products. It converts foreign trade data into categories of final or intermediate use, such us capital goods, intermediate goods or consumer goods, following the usage in the System of National Accounts (SNA). We grouped BEC items into five stages of production as following:

\begin{tabular}{|c|c|c|c|}
\hline 3 stages & 5 stages & $\begin{array}{l}\text { Code } \\
\text { BEC }\end{array}$ & $\begin{array}{l}\text { Title } \\
\text { BEC }\end{array}$ \\
\hline \multirow[t]{3}{*}{ Primary goods } & & 111 & Food and beverages mainly for industry \\
\hline & & 21 & Industrial supplies, n.e.s., primary \\
\hline & & 31 & Fuels and lubricants, primary \\
\hline \multirow{5}{*}{$\begin{array}{l}\text { Intermediate } \\
\text { goods }\end{array}$} & Semi-finished goods & 121 & Food and beverages, processed, mainly for industry \\
\hline & & 22 & Industrial supplies, n.e.s., processed \\
\hline & & 322 & Fuels and lubricants, processed \\
\hline & Parts\&components & 42 & Of capital goods, except transport equipment \\
\hline & & 53 & Parts and accessories of transport equipment \\
\hline \multirow[t]{9}{*}{ Final goods } & Capital goods & 41 & Capital goods except transport equipment \\
\hline & & 521 & Other industrial transport equipment \\
\hline & Consumption goods & 112 & Food \& bev., primary, mainly for household consumption \\
\hline & & 122 & Food \& bev., primary, processed, for house. consumption \\
\hline & & 51 & Passenger motor cars \\
\hline & & 522 & Other non-industrial transport equipment \\
\hline & & 61 & Durable consumer goods n.e.s. \\
\hline & & 62 & Semi-durable consumer goods n.e.s. \\
\hline & & 63 & Non-durable consumer goods n.e.s. \\
\hline
\end{tabular}




\section{APPENDIX 5 - THE DEFINITION OF HIGH-TECH PRODUCTS}

The definition of high-technology products is based on indicators of technological intensity in OECD countries, such as R\&D expenditures divided by value added, $R \& D$ expenditures divided by production.

On the basis of this definition two types of classification can be made of high-technology products:

- at a broad category level: the indicators of high-tech content are calculated at the branch level and all the products within an high-tech branch are considered as selected "hightech" products;

- at a detailed product level within a broad category.

The first methodology is the most widely used. For instance, the latest OECD classification (2004) based on technology indicators groups manufacturing branches (ISIC rev.3, at 2 or 3 digit level) into 4 technological levels: high-technology, medium-high-technology; medium-low-technology; and low technology. In this classification high-technology industries includes all products belonging to the following branches:

- $\quad$ aircraft and spacecraft (ISIC 353);

- pharmaceuticals (ISIC 2423);

- office, accounting, and computing machinery (ISIC 30);

- radio, TV and communication equipment (ISIC 32);

- medical, precision and optical instrument (ISIC 33).

In the same way, according to World Development Indicators of United Nations (WDI database), high-technology exports include all the exports of the following branches: aerospace, computers, pharmaceuticals, scientific instruments, and electrical machinery. Figure 5 in present study refers to this definition.

It has to be noted that this methodology introduces a serious selection bias, since not all product in a "high-technology industry" necessarily have a high technology content. Likewise, some products in industries with low technology intensity may well incorporate a high degree of technological sophistication.

The second methodology first defines large high-tech sectors (as described above) and then selects, within this high-tech branches and a detailed level of the products having a high content in R\&D. The definition of high-tech products used in CEPII studies refers to this second way (Fontagné et alii, 1999). The nine high-tech industries that were selected in the first step were the following: 
- aerospace;

- computers, office machinery;

- electronics-communications;

- pharmaceuticals;

- $\quad$ scientific instruments;

- electrical machinery;

- chemicals;

- other transport equipment;

- non-electrical machinery;

- weapons.

In the second step, within these broad categories, a list of 252 products (at the 6 digits level of the Harmonised System) were identified as high-tech. It has to be noted that this methodology introduces another selection bias, since it examines whether products are of a high-technology nature or not, only in branches that are considered high-technology: the high-technology products belonging to non technological branches are thus implicitly considered as non-technological. 


\section{LIST OF WORKING PAPERS RELEASED BY CEPII ${ }^{9}$}

No

Title

2006-04 Who Pays China's Bank Restructuring Bill?

2006-03 Structural Determinants of the Exchange-Rate PassThrough

2006-02 Exchange-Rate Pass-Through at the Product Level

2006-01 Je t'aime, moi non plus : Bilateral Opinions and International Trade

2005-23 World Trade Competitiveness: A Disaggregated View by Shift-Share Analysis

2005-22 Chômage et réformes du marché du travail au Japon

2005-21 Profitability of Foreign and Domestic Banks in Central and Eastern Europe: Does the Mode of Entry Matter?

2005-20 ECB Governance in an Enlarged Eurozone

2005-19 What Are EU Trade Preferences Worth for SubSaharan Africa and Other Developing Countries?

2005-18 Binding Overhang and Tariff-Cutting Formulas

2005-17 International Trade and Income Distribution: Reconsidering the Evidence

2005-16 China and the Relationship between the Oil Price and the Dollar
Authors

G. Ma

G. Gaulier,

A. Lahrèche-Révil

\& I. Méjean

G. Gaulier,

A. Lahrèche-Révil

\& I. Méjean

A.C. Disdier

\& T. Mayer

A. Cheptea, G. Gaulier \& S. Zignago

E. Dourille-Feer

O. Havrylchyk \&

E. Jurzyk

A. Bénassy-Quéré \&

E. Turkisch

F. Candau \& S. Jean

M.H. Bchir, S. Jean \&

D. Laborde

I. Bensidoun, S. Jean \&

A. Sztulman

A. Bénassy-Quéré, V. Mignon \& A. Penot

\footnotetext{
9

Working papers are circulated free of charge as far as stocks are available; thank you to send your request to CEPII, Sylvie Hurion, 9, rue Georges-Pitard, 75015 Paris, or by fax : (33) 0153685504 or by e-mail Hurion@cepii.fr. Also available on: Nwww.cepii.fr. Working papers with * are out of print. They can nevertheless be consulted and downloaded from this website.

9 Les documents de travail sont diffusés gratuitement sur demande dans la mesure des stocks disponibles. Merci d'adresser votre demande au CEPII, Sylvie Hurion, 9, rue Georges-Pitard, 75015 Paris, ou par fax : (33) 0153685504 ou par e-mail Hurion@cepii.fr. Egalement disponibles sur: ॥www.cepii.fr. Les documents de travail comportant* sont épuisés. Ils sont toutefois consultable sur le web CEPII.
} 
2005-15 Consequences of Alternative Formulas for Agricultural Tariff Cuts

2005-14 Is Erosion of Tariff Preferences a Serious Concern?

2005-13 The Consequences of Agricultural Trade Liberalization for Developing Countries: Distinguishing Between Genuine Benefits and False Hopes

2005-12 From Bound Duties to Actual Protection: Industrial Liberalisation in the Doha Round

2005-11 Impact de l'ouverture financière sur les inégalités internes dans les pays émergents

2005-10 Disentangling Horizontal and Vertical Intra-Industry Trade

2005-09 China's Integration in East Asia: Production Sharing, FDI \& High-Tech Trade

2005-08 Tax Competition and Public Input

2005-07 Trade Liberalisation, Growth and Poverty in Senegal: A Dynamic Microsimulation CGE Model Analysis

2005-06 Migration, Trade and Wages

2005-05 Institutional Determinants of Foreign Investment

2005-04 L'économie indienne: changements structurels et perspectives à long terme

2005-03 Programme de travail du CEPII pour 2005

2005-02 Market Access in Global and Regional Trade

2005-01 Real Equilibrium Exchange Rate in China

2004-22 A Consistent, ad-valorem Equivalent Measure of Applied Protection Across the World: The MacMapHS6 Database
S. Jean, D. Laborde \& W. Martin

A. Bouët, L. Fontagné \& S. Jean

J.C. Bureau, S. Jean

A. Matthews

M.H. Bchir,

L. Fontagné \& S. Jean

A. Bénassy-Quéré \& V. Salins

L. Fontagné, M. Freudenberg \& G. Gaulier

G. Gaulier, F. Lemoine D. Ünal-Kesenci

A. Bénassy-Quéré, N. Gobalraja \&

A. Trannoy

N. Annabi, F. Cissé, J. Cockburn \& B. Decaluwé

A. Hijzen \& P. Wright

A. Bénassy-Quéré, M. Coupet \& T. Mayer

S. Chauvin \&

F. Lemoine

T. Mayer \& S. Zignago

V. Coudert \&

C. Couharde

A. Bouët, Y. Decreux, L. Fontagné, S. Jean \& D. Laborde 
2004-21 IMF in Theory: Sovereign Debts, Judicialisation and Multilateralism

2004-20 The Impact of Multilateral Liberalisation on European Regions: a CGE Assessment

2004-19 La compétitivité de l'agriculture et des industries agroalimentaires dans le Mercosur et l'Union européenne dans une perspective de libéralisation commerciale

2004-18 Multilateral Agricultural Trade Liberalization: The Contrasting Fortunes of Developing Countries in the Doha Round

2004-17 UK in or UK out? A Common Cycle Analysis between the UK and the Euro Zone

2004-16 Regionalism and the Regionalisation of International Trade

2004-15 The Stock-Flow Approach to the Real Exchange Rate of CEE Transition Economies

2004-14 Vieillissement démographique, épargne et retraite : une analyse à l'aide d’un modèle d'équilibre général à agents hétérogènes

2004-13 Burden Sharing and Exchange-Rate Misalignments within the Group of Twenty

2004-12 Regulation and Wage Premia

2004-11 The Efficiency of Fiscal Policies: a Survey of the Literature

2004-10 La réforme du marché du travail en Allemagne : les enseignements d'une maquette

2004-09 Typologie et équivalence des systèmes de retraites

2004-08 South - South Trade: Geography Matters

2004-07 Current Accounts Dynamics in New EU Members: Sustainability and Policy Issues

2004-06 Incertitude radicale et choix du modèle
J. Sgard

S. Jean \& D. Laborde

N. Mulder, A. Vialou,

B. David,

M. Rodriguez \&

M. Castilho

A. Bouët, J.C. Bureau,

Y. Decreux \& S. Jean

J. Garnier

G. Gaulier, S. Jean \&

D. Ünal-Kesenci

B. Egert,

A. Lahrècche-Révil \&

K. Lommatzsch

C. Bac \& J. Chateau

A. Bénassy-Quéré, P. Duran-Vigneron,

A. Lahrèche-Révil \& V. Mignon

S. Jean \& G. Nicoletti

S. Capet

S. Capet

P. Villa

S. Coulibaly \&

L. Fontagné

P. Zanghieri

P. Villa 


\section{CEPII \\ DOCUMENTS DE TRAVAIL / WORKING PAPERS}

Si vous souhaitez recevoir des Documents de travail, merci de remplir le coupon-réponse ci-joint et de le retourner à :

Should you wish to receive copies of the CEPII's Working papers, just fill the reply card and return it to:

Sylvie HURION - Publications

CEPII - 9, rue Georges-Pitard - 75740 Paris - Fax : (33) 1.53.68.55.04

sylvie.hurion@cepii.fr

M./Mme / Mr./Mrs

Nom-Prénom / Name-First name

Titre / Title.....

Service / Department

Organisme / Organisation

Adresse / Address.

Ville \& CP / City \& post code.

Pays / Country...... Tél.

Your e-mail

Désire recevoir les Document de travail du CEPII $n^{\circ}$ :

Wish to receive the CEPII's Working Papers No:

Souhaite être placé sur la liste de diffusion permanente (pour les bibliothèques)

Wish to be placed on the standing mailing list (for Libraries). 